\title{
Vigeland and the Status of Cultural Concerns in Trade Mark Law - The EFTA Court Develops More Effective Tools for the Preservation of the Public Domain
}

\author{
Martin Senftleben
}

Published online: 4 September 2017

(C) The Author(s) 2017. This article is an open access publication

\begin{abstract}
The Vigeland decision of the EFTA Court is a milestone in the preservation of the public domain of cultural creations. It paves the way for an important and welcome recalibration of the copyright/trade mark interface. The Court departs from the traditional approach which relies on non-distinctiveness, descriptiveness or genericness to reject trade mark rights. Instead, the Court provides exemplary lines of argument for the application of considerations of public policy and principles of morality as grounds for refusal. As a refusal based on these grounds cannot be overcome through use in trade, this rejection of a registration request leads to an outright exclusion from trade mark protection and a robust preservation of a work's public domain status. National offices and courts should follow in the footsteps of the EFTA Court to avoid that trade mark law provides dysfunctional incentives for the re-privatization of cultural public domain material. In this way, they can also avoid that public money is wasted on the acquisition and maintenance of a costly trade mark portfolio relating to artworks.
\end{abstract}

Keywords Public domain preservation · Copyright/trade mark interface · Grounds for refusal · Public policy · Accepted principles of morality · Functionality doctrine

M. Senftleben $(\bowtie)$

Ph.D.; Professor of Intellectual Property and Director, Kooijmans Institute for Law and Governance,

Vrije Universiteit Amsterdam; of Counsel, Bird \& Bird, (The Hague, The Netherlands), Amsterdam,

The Netherlands

e-mail: m.r.f.senftleben@vu.nl 


\section{The Vigeland Case}

In the Vigeland case, ${ }^{1}$ the Court of Justice of the European Free Trade Association States (hereinafter EFTA Court) was called upon to assess an attempt to register several artworks made by Gustav Vigeland - one of the most eminent Norwegian sculptors - as trade marks. The reason for the initiative to acquire trade mark rights was the expiry of the term of copyright protection. ${ }^{2}$ The prejudicial questions came from the Norwegian Board of Appeal for Industrial Property Rights. The Board of Appeal was wondering about the application of several grounds for refusal in this case. ${ }^{3}$ Among other works, the underlying trade mark application concerned Vigeland's "Monolith" (Monolitten) and "Angry Boy" (Sinnataggen) - popular works which feature prominently in the Vigeland Installation in the centre of Oslo's Frogner Park. Interestingly, the registration initiative was not taken by a trade mark "troll" seeking to obtain rights to popular artistic works for the sole purpose of threatening users with infringement claims and pressing for excessive licence fees without any intention to make genuine use of the works itself. ${ }^{4}$

By contrast, the trade mark application was filed by the Municipality of Oslo. In respect of this remarkable step, the Municipality submitted arguments to the EFTA Court which are derived from a distinction between Vigeland's artistic work on the one hand, and Oslo's commercial marketing efforts on the other. In particular, the city argued that "[a]ll of the shapes have been exclusively connected to, and used by or through, the Municipality since the death of Gustav Vigeland in 1943. Many of these shapes are well known and valuable, in particular, due to the efforts and investments made by the Municipality." 5

Hence it seems that from the perspective of the Municipality of Oslo, the rights to Vigeland's works ought to be due to the city - even after copyright expiry - because of the efforts made to ensure that the works became well known. Oslo stated that against this background no other entity could have justifiable interests in the commercial exploitation of Vigeland's works. ${ }^{6}$ The Municipality also pointed out that it had specifically been chosen by Gustav Vigeland to administer and safeguard his artistic reputation and memory. ${ }^{7}$ Nonetheless, considerations of art custodianship, such as the need to preserve the genuine cultural meaning of Vigeland's works by preventing third

\footnotetext{
${ }^{1}$ EFTA Court, 6 April 2017, Case E-5/16, Municipality of Oslo ("Vigeland"); for the headnotes to this decision see this issue of IIC at doi:10.1007/s40319-017-0629-3.

2 EFTA Court, ibid., para. 20. Gustav Vigeland died on 12 March 1943.

3 EFTA Court, ibid., paras. 28-30.

${ }^{4}$ For a case that has arisen from this practice, see Dresden Court of Appeal, 4 April 2000, case 14 U 3611/99, "Johann Sebastian Bach", in: Neue Juristische Wochenschrift 2001, p. 615. The case concerned the registration of the name and portrait of Johann Sebastian Bach as a trade mark for various goods and services, including glassware, porcelain and crockery. While the trade mark proprietor had not commenced using the sign himself, he systematically asserted his trade mark rights against users referring to Johann Sebastian Bach. $C f$. the background information given by Götting (2001), p. 615.

5 Report for the Hearing, Judge-Rapporteur Baudenbacher, 5 October 2016, case E-5/16, Municipality of Oslo ("Vigeland"), para. 32.

${ }^{6}$ Report for the Hearing, ibid., para. 36.

7 Report for the Hearing, ibid., para. 36.
} 
parties from attaching undesirable commercial connotations, did not play a central role in the submission to the EFTA Court. ${ }^{8}$ Instead, the Municipality insisted that "it should be assessed whether the value and fame of the work are related to characteristics and qualities of the artwork alone, or if the value and renown may be attributed to investments and efforts made by the Municipality."9

With this strategy, the city of Oslo had little success in its own country. The Norwegian Industrial Property Office remained unimpressed and refused the trade mark application on the grounds that Vigeland's works were non-distinctive, descriptive and functional. The shape of the works added substantial value to at least some of the goods, in respect of which registration was sought. ${ }^{10}$ Instead of dispelling these concerns, the Board of Appeal decided to supplement the list of grounds for refusal with a further counterargument. It expressed the view that a trade mark registration of works belonging to the cultural heritage may be contrary to public policy or accepted principles of morality, and wondered which factors should inform the decision on these grounds for refusal. ${ }^{11}$

Apart from this central point (which is the focus of the following discussion in Sects. 2-5), the Board of Appeal asked whether the statutory exclusion of substantial value shapes was applicable to two-dimensional representations of sculptures, and how the distinctiveness of two- or three-dimensional representations of sculptures should be assessed. These latter points will be revisited in Sect. 6 before drawing conclusions in Sect. 7.

\section{Acceptance of Simultaneous and Subsequent Trade Mark Protection}

Before turning to the decision of the EFTA Court, it is important to note that the approach advocated by the Municipality of Oslo reflects the traditional carelessness vis-à-vis cultural concerns that often comes to the fore in decisions on cumulative copyright and trade mark protection. While the functionality doctrine in EU trade mark law prevents overlaps between patent and trade mark protection ${ }^{12}$ and ensures a far-reaching separation of industrial designs and trade mark protection, ${ }^{13}$ a comparably strong mechanism for policing the border between copyright and trade mark protection has not evolved yet. ${ }^{14}$

On the contrary, the cumulation of copyright and trade mark protection is often deemed unproblematic even though copyright law, as patent and industrial design legislation, only offers a limited period of protection and rests on a clear quid pro quo: in return for the grant of protection, the legislator expects an enrichment of the public domain at the end of the term of copyright protection. Evidently, the acceptance of

\footnotetext{
${ }^{8}$ Report for the Hearing, ibid., paras. 31-42.

9 Report for the Hearing, ibid., para. 37.

10 EFTA Court, 6 April 2017, case E-5/16, Municipality of Oslo ("Vigeland"), para. 27.

11 EFTA Court, ibid., paras. 28-30.

12 CJEU, 18 June 2002, case C-299/99, Philips/Remington, para. 82.

13 CJEU, 18 September 2014, case C-205/13, Hauck/Stokke, paras. 19-20.

14 Senftleben (2013a), pp. 814-817.
} 
cumulative trade mark protection compromises this copyright policy because trade mark law offers the option of indefinitely renewable rights. The Court of Justice of the European Union (CJEU) is well aware of this dilemma. In Philips/Remington (concerning the patent/trade mark interface), the CJEU already referred to the "legitimate aim of not allowing individuals to use the registration of a mark in order to acquire or perpetuate exclusive rights relating to technical solutions." ${ }^{15}$ In Hauck/ Stokke (addressing the industrial designs/trade mark interface), the Court, even more broadly, recognized the objective "to prevent the exclusive and permanent right which a trade mark confers from serving to extend indefinitely the life of other rights which the EU legislature has sought to make subject to limited periods."16

As explained, copyright is such a right with a limited period. To date, however, the CJEU has not had the opportunity to invoke this line of reasoning to regulate the relationship between copyright and trade mark protection. The General Court of the European Union (GCEU) approached the question in the traditional, schematic way in Danjaq/OHIM (Mission Productions). The case concerned an opposition brought by Danjaq against Mission Production's attempt to register the sign "Dr. No" - the title of the first James Bond film and the name of James Bond's antagonist - as a trade mark. Commenting on the possibility of copyright/trade mark overlaps in this context, the Court pointed out that

[t]he same sign may be protected as an original creative work by copyright and as an indicator of commercial origin by trade mark law. It is therefore a matter of different exclusive rights based on distinct qualities, that is to say the original nature of a creation, on the one hand, and the ability of a sign to distinguish the commercial origin of the goods and services, on the other. ${ }^{17}$

Hence, the Court readily accepted the protection overlap on the ground that trade mark rights do not offer protection for a cultural creation as such, but only for certain functions which the cultural creation fulfils as a distinctive sign in respect of goods and services to which it is attached. ${ }^{18}$ In this vein, the Court stated that "only signs which develop characteristic trade mark functions" ${ }^{19}$ were eligible for trade mark protection. It rejected trade mark rights to "Dr. No" because the sign would be perceived as a mere descriptive reference to the film and not as an identifier of commercial source. ${ }^{20}$ Nonetheless, the decision confirms the possibility of combining copyright and trade mark protection in cases where a literary or artistic work also functions as a distinctive sign.

Similar considerations play a role in national court decisions. The Dutch Supreme Court, for instance, traditionally permits the cumulative assertion of copyright and trade mark claims. ${ }^{21}$ In recent decisions, the Court added that a holder

\footnotetext{
15 CJEU, 18 June 2002, case C-299/99, Philips/Remington, para. 82.

16 CJEU, 18 September 2014, case C-205/13, Hauck/Stokke, paras. 19-20.

17 GCEU, 30 June 2009, case T-435/05, Danjaq/OHIM (Mission Productions), para. 26.

18 Stieper (2012), pp. 1090-1091 and Peukert (2012), pp. 111-113.

19 GCEU, ibid., para. 26.

${ }^{20}$ GCEU, ibid., paras. 25-28.

21 Dutch Supreme Court, 16 April 1999, case number 9098 (R97/163HR), in: Nederlandse Jurisprudentie 1999, No. 697, Bigott-Batco/Doucal, para. 3.9. Cf. Cohen Jehoram et al. (2010), p. 556.
} 
of rights under trade mark and copyright law could invoke both rights simultaneously only if he had a distinct interest in the protection following from each individual right. ${ }^{22}$ However, this additional condition need not constitute a substantial hurdle. If the cumulation of rights is accepted on the ground that copyright protects a cultural creation as such, whereas trade mark law protects specific trade mark functions, it is easy to justify the assertion of trade mark rights by pointing to the interest in preserving the trade mark features of the intellectual creation concerned. ${ }^{23}$ The Dutch Supreme Court relied on similar considerations to explain the acceptance of combined copyright and trade mark claims. ${ }^{24}$

The result is a rather low, if not negligible, threshold for the cumulation of copyright and trade mark protection. If the difference between the purpose and configuration of the two protection regimes is already sufficient to justify overlapping rights, there seems to be no substantial obstacle to the assertion of cumulative protection in case of subject matter capable of constituting both an original work and a trade mark. In any case, courts do not seem hesitant to hear claims based on cumulative copyright and trade mark protection. Without CJEU decisions that curtail rights cumulation practices, judges are free to develop rather elastic tests of eligibility for a combined claim, such as the test of "different exclusive rights based on distinct qualities" used by the GCEU or the "distinct interest in protection" requirement introduced by the Dutch Supreme Court.

The Vigeland case clearly shows the potentially corrosive effect of this approach on the public domain of cultural creations. Strictly speaking, the situation that gave rise to the prejudicial questions differed markedly from typical cumulation cases. While the combination of copyright and trade mark rights has become a standard strategy in the area of character merchandising (leading to simultaneous trade mark protection and "true" cumulation of copyright and trade mark rights), ${ }^{25}$ it has not become a widespread practice in the field of cultural heritage signs belonging to the public domain (characterized by an attempt to obtain subsequent trade mark protection after the expiry of copyright or in respect of cultural heritage material that is older than any copyright statute). ${ }^{26}$ Until now, artists seeking to create new

\footnotetext{
22 Dutch Supreme Court, 8 September 2006, case LJN AV3384, Benetton/G-Star, para. 3.11. Cf. Quanjel-Schreurs (2007), pp. 80-83.

23 Stieper (2012), pp. 1090-1091 and Peukert (2012), pp. 111-113.

24 Dutch Supreme Court, 8 September 2006, case LJN AV3384, Benetton/G-Star, para. 3.11.

25 Cf. Calboli (2014a), pp. 29-30. Examples can easily be found in trade mark registers. As to Mickey Mouse, see http://www.wipo.int/romarin for the international registration No. 296478. As to Superman, see https://register.dpma.de/DPMAregister/marke/einsteiger?lang=en for the German registration DD643100. As to Miffy, see https://register.boip.int/bmbonline/intro/show.do for the Benelux registration No. 0653451 .

26 This is not to say that registrations of cultural heritage signs have not taken place at all; see Bugdahl (2010), pp. 372-373. The central point is, however, that this has not yet become a standard practice in respect of artworks in the public domain. For examples of registrations relating to the names of artists (rather than their works), see CTM 001081314, BEETHOVEN; CTM 000945774, DESCARTES; CTM 001593128, ALBERT EINSTEIN; CTM 003805942, GOETHE; IR 0858800, HENRIK IBSEN; CTM 001358621, VINCENT VAN GOGH; CTM 005468996, MONA LISA; CTM 000021071 MOZART; CTM 001334036, PICASSO; CTM 000119354, REMBRANDT; CTM 004278214, SHAKESPEARE; CTM 003877354, GIUSEPPE VERDI; CTM 000047365, VERMEER; CTM 000996199, LEONARDO DA VINCI; CTM 003437811, ANDY WARHOL.
} 
literary and artistic works on the basis of public domain works are not regularly confronted with trade mark infringement claims.

With the approach taken by the Municipality of Oslo, however, this status quo could change soon. On its merits, the Municipality adopts the argument of "different exclusive rights based on distinct qualities" which is known from character merchandising, and extends this approach to public domain works. As explained, Oslo's core argument is the effort made to enhance the reputation of Vigeland's works. According to the city, the commercial "value and renown" which Vigeland's works enjoy, are attributable to investments and efforts made by the Municipality. ${ }^{27}$ To obtain trade mark protection, the city of Oslo thus seeks to separate artistic merit (the copyright aspect) from commercial selling power (the trade mark aspect). As, in the city's view, the latter aspect of Vigeland's works is due to Oslo's marketing efforts, the intellectual property right relating to this aspect - namely the trade mark right - must also be due to the city. Following this approach, the schematic distinction between "different exclusive rights based on distinct qualities" thus serves as a vehicle to re-appropriate artworks which have already entered the public domain.

Admittedly, the Municipality of Oslo seems unlikely to behave like a typical cultural heritage "grabber" or trade mark "troll". If, however, Oslo manages to register Vigeland's works as trade marks, this success may serve as an example for similar initiatives by various other players. As an element of museum, city, region or nation branding, ${ }^{28}$ public institutions ranging from museums to governments may seek trade mark protection for artworks. In parallel, private enterprises could invest in cultural heritage signs with favourable cultural connotations as part of their brand development strategy.

In consequence, the conditions surrounding the creation of derivative works would change significantly. The use of cultural heritage works that have entered the public domain would no longer be as free as it was in the past. Currently, artists can rely on freedom of use when they base their creations on public domain works. As long as public domain material remains unencumbered with intellectual property rights, the risk of a lawsuit arising from unauthorized use can be excluded from the outset. With the registration of cultural symbols as trade marks, this freedom is sacrificed in favour of a scenario in which trade mark rights can serve as a basis for an infringement action. If commercial entities and other public bodies follow Oslo's example and start investing in public domain works in order to acquire trade mark rights, the climate change in respect of reuse and remix of cultural heritage material will be considerable.

In addition, the Vigeland case raises the question whether public money that is invested in the acquisition and maintenance of a portfolio of trade-marked artworks is well spent. The acquisition of trade mark rights requires investment in campaigns that educate consumers to perceive the sign not only as an artwork but also as an

\footnotetext{
${ }^{27}$ Report for the Hearing, Judge-Rapporteur Baudenbacher, 5 October 2016, case E-5/16, Municipality of Oslo ("Vigeland"), para. 37.

28 For an example of such an initiative taken by the State of Bavaria in respect of Neuschwanstein Castle, see the pending case before the CJEU, case C-488/16 P, Bundesverband Souvenir- GeschenkeEhrenpreise/EUIPO (Neuschwanstein), which evolved from an appeal against the confirmation of trade mark rights in GCEU, 5 July 2016, case T-167/15, Bundesverband Souvenir- Geschenke- Ehrenpreise/ EUIPO (Neuschwanstein).
} 
identifier of commercial source. The maintenance of trade mark rights requires genuine use of the artworks in the sense of trade mark law - use to create or preserve an outlet for goods or services. ${ }^{29}$ Arguably, public bodies, in particular museums and other cultural heritage institutions, contribute to the preservation of cultural artefacts and support an open and well-informed communication process in respect of artworks in a much more efficient way when they focus on their primary tasks instead of becoming trade mark portfolio managers.

Finally, the prospect of public institutions enforcing trade mark rights that relate to artworks gives rise to concerns about censorship. Intentionally or unintentionally, the Municipality of Oslo may bring trade mark claims against those forms of unauthorized use which, from its point of view, denigrate Vigeland's works (and, therefore, damage the reputation of its trade marks), whereas it may refrain from taking action against artists who comply with its own understanding of the message and meaning of the artworks (and, thus, are no threat to the "value and renown" of the trade marks).

\section{Reliance on Checks and Balances in Trade Mark Law}

Oslo's plan to register several Vigeland masterpieces is not the first trade mark registration initiative relating to cultural material that has given rise to these, or similar, concerns. Posing its prejudicial questions, the Board of Appeal referred to the CJEU case Shield Mark which concerned an attempt to register, among other signs, the first nine notes of Beethoven's piano piece "Für Elise". ${ }^{30}$ Discussing the registration of this melody, Advocate General Ruiz-Járabo Colomer explicitly addressed the public domain dimension of the case. He expressed the view that it was difficult to accept

that a creation of the mind, which forms part of the universal cultural heritage, should be appropriated indefinitely by a person to be used on the market in order to distinguish the goods he produces or the services he provides with an exclusivity which not even its author's estate enjoys. ${ }^{31}$

Concerns about the re-appropriation of cultural heritage material on the basis of trade mark law have thus been expressed earlier at the EU level. Nonetheless, it seems that there is still broad support for cumulative copyright and trade mark protection.

\subsection{Statements in Literature}

In literature, a rather uncritical view seems to prevail. The possibility of combining copyright and trade mark protection is often mentioned without much commentary

\footnotetext{
${ }^{29}$ CJEU, 11 March 2003, case C-40/01, Ajax/Ansul, paras. 36 and 43. Cf. Kur and Senftleben (2017), para. 6.157-6.163.

30 EFTA Court, 6 April 2017, case E-5/16, Municipality of Oslo ("Vigeland"), para. 30.

31 Opinion of Advocate General Ruiz-Járabo Colomer, 3 April 2003, case C-283/01, Shield Mark/Kist, para. 52 .
} 
on the potential risks for cultural follow-on innovation, or is accepted on the ground that trade mark rights do not offer protection for a cultural creation as such, but only for certain functions which the cultural creation fulfils as a distinctive sign in respect of goods and services to which it is attached. ${ }^{32}$ Arguing in favour of an entitlement of rights owners to accumulate copyright and trade mark protection, Tobias Cohen Jehoram, Constant van Nispen and Tony Huydecoper posit that

[i]n principle, there is no objection against cumulation or concurrence of trademark rights and copyrights and the benefits of the two protection regimes exist independently for the two rights. The proprietor of these rights satisfied all requirements stipulated by the different laws, so that there is no reason to limit the protection under one of the legal regimes for the sole reason that another legal protection exists. ${ }^{33}$

Besides this maximalist view which readily accepts the cumulation of rights as a corollary of formal eligibility for protection under copyright and trade mark law, more nuanced approaches have also evolved in the debate. Annette Kur pointed out that the cumulation of different intellectual property rights was only unproblematic as long as the individual protection regimes involved were balanced in the sense that the prerequisites for obtaining protection were appropriately aligned with the contents and limits of exclusive rights. ${ }^{34}$ Cumulation thus required a thorough scrutiny in the light of the checks and balances offered by the protection regimes involved. If these checks and balances are sufficient to prevent excessive protection that obstructs competition, the cumulation of copyright and trade mark rights is acceptable. $^{35}$ Otherwise, however, overlapping protection raises the problem of "asymmetric convergence" and requires appropriate countermeasures. ${ }^{36}$

Turning to the spectrum of critical statements, the position taken by Feer Verkade is of particular interest. He expressed concerns about the corrosive effect of overlapping protection on the individual balance and structure of copyright and trade mark law. Instead of affording rights owners the opportunity to always enjoy the "best of both worlds", they should be bound to accept the "one world" offered by each individual law. ${ }^{37}$ Hence, potentially indefinite trade mark protection should not be available as a vehicle to undermine the limited term of copyright protection and the absence of formalities in copyright law should not allow the circumvention of the registration requirement in (Benelux) trade mark law. ${ }^{38}$ Seeking to prevent one protection regime from blurring the conceptual contours of the other, Verkade proposes to determine on a case-by-case basis whether the trade mark or copyright aspect takes precedence. ${ }^{39}$ Following this approach, a

\footnotetext{
32 Stieper (2012), pp. 1090-1091 and Peukert (2012), pp. 111-113.

33 Cohen Jehoram, van Nispen and Huydecoper 2010, p. 556.

${ }^{34}$ Kur (2001), pp. 45 and 50. Cf. Kur (2011), p. 9.

35 Kur (2001), p. 44.

${ }^{36}$ Kur (2001), pp. 42-44; see also the analysis conducted by McGuire (2011), p. 774, who arrives at a similar conclusion.

37 Verkade (1998), p. 72.

38 Verkade (1998), p. 72.

39 Verkade (1998), p. 73.
} 
rights owner would thus be prevented from asserting copyright and trade mark protection cumulatively even if the intellectual creation concerned is eligible for protection under both regimes. After the expiry of copyright protection, the fact that the work has entered the public domain in accordance with the copyright rule of a limited term of protection constitutes a factor weighing against "precedence" of trade mark protection - at least in case of genuine cultural expressions, such as "Dik Trom", the main character and title of a famous Dutch children's book series. ${ }^{40}$

The critical comments on trade mark/copyright overlaps, finally, comprise proposals seeking to eliminate cumulative copyright and trade mark protection for literary and artistic works altogether. A categorical rejection of the cumulation of rights can result from a strong preference for freedom of competition based on the public interest in the optimal use of intellectual resources and the encouragement of follow-on innovation after the expiry of the limited term of copyright protection. ${ }^{41}$ If the constant enrichment and cultivation of the public domain is qualified as an element of the ordre public, an amalgam of copyright and trade mark rights which allows the continuation of trade mark protection after copyright expiry can also be deemed impermissible because it withholds literary and artistic works from the public domain and causes a conflict with public order and morality for this reason. ${ }^{42}$

\subsection{Approach Taken in Practice}

In practice, however, the courts seem reluctant to adopt positions leading to the full separation of copyright and trade mark protection. ${ }^{43}$ Even nuanced approaches, such as Verkade's proposal to determine the predominant protection aspect case-by-case, have not made their way into court decisions. Instead, judges seem to favour the rather uncritical attitude vis-à-vis cumulative copyright and trade mark protection that comes to the fore in many literature statements. The aforementioned GCEU decision in Danjaq/OHIM (Mission Productions) clearly follows this approach. ${ }^{44}$

Hence, the question arises why - despite concerns about the re-privatization of cultural heritage material and an impoverishment of the public domain of cultural expression - the copyright/trade mark interface has not been recalibrated yet. On the basis of Annette Kur's assessment of the overlap problem, ${ }^{45}$ it may be said that, to this day, judges seem to be confident that they can solve cases concerning cumulative copyright/trade mark protection satisfactorily by employing the tools available in the respective protection regimes. ${ }^{46}$ More concretely, they seem to assume that the checks and balances in trade mark law are sufficient to prevent an encroachment upon the public domain of cultural expression.

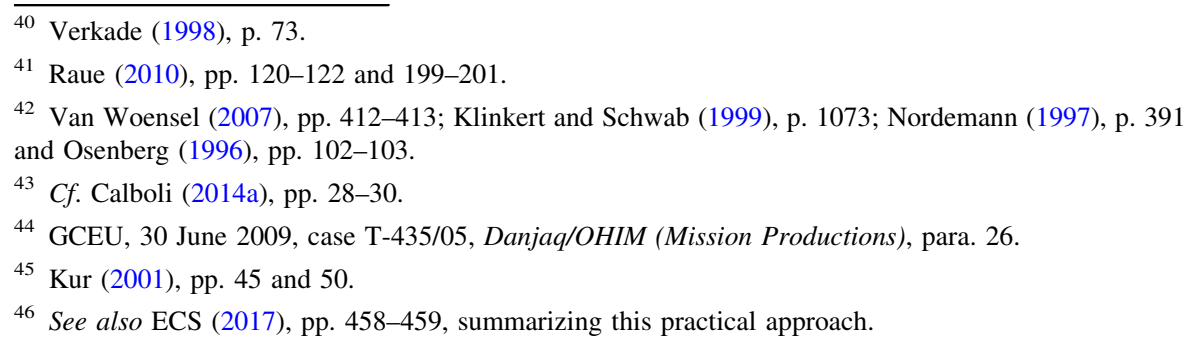


Unfortunately, the "Für Elise" application underlying the Shield Mark case did not culminate in a CJEU statement addressing this point. The application for registration was a test case seeking to explore the elasticity of the requirement of graphical representation in the case of sound marks. Accordingly, the Court did not discuss the validity of the policy argument advanced by Advocate General RuizJárabo Colomer. Instead, it only clarified the practical point that, in the case of a melody, the requirement of graphical representation could be satisfied by providing standard musical notation. ${ }^{47}$ In its request for a prejudicial ruling in the Vigeland case, the Norwegian Board of Appeal also mentioned the German Mona Lisa case which concerned an attempt to register the famous da Vinci painting as a trade mark. ${ }^{48}$ In this case, the traditional reliance on standard checks and balances of the trade mark system clearly comes to the fore.

\subsection{No Registration Because of Lack of Distinctiveness}

Rejecting the Mona Lisa application, the German Federal Patent Court held that the applicant had failed to establish the requisite distinctiveness. Because the painting was frequently used by third parties in advertising, the public would regard the Mona Lisa as a mere advertising instrument rather than as an indication of source. ${ }^{49}$ The Court also held that, because of the frequent use in advertising, the painting had become customary in established trade practices. ${ }^{50}$ However, the Court was unwilling to accept the further argument that registration of the Mona Lisa was contrary to public policy or accepted principles of morality. In the Court's view, the appropriation of the Mona Lisa on the basis of trade mark law would not violate the principle that cultural expressions should remain freely available for the public after the expiry of copyright protection. ${ }^{51}$

Instead of openly addressing the cultural dimension of the trade mark application, the German Federal Patent Court thus relied exclusively on the basic trade mark requirement of distinctiveness. As a result, the decision seems detached from the core problem of the case. The solution based on a lack of distinctiveness precludes a meaningful discussion of the potential erosion of the freedom of using public domain works without any fear of exposure to a trade mark infringement action. It also precludes a discussion of the intention underlying the attempt to register the Mona Lisa. The trader filing the application may seek to exploit the positive cultural connotations and the popularity of the sign which is the result of its status in the cultural domain. This may lead to an unfair commercial advantage and be qualified as unfair free-riding in comparison with the efforts to be undertaken by other traders who must develop the reputation of their trade marks "from scratch".

\footnotetext{
47 CJEU, 27 November 2003, case C-283/01, Shield Mark/Kist, para. 64.

48 EFTA Court, 6 April 2017, case E-5/16, Municipality of Oslo ("Vigeland"), para. 29.

49 German Federal Patent Court, 25 November 1997, case 24 W (pat) 188/96, Mona Lisa, in: Gewerblicher Rechtsschutz und Urheberrecht 1998, pp. 1022.

50 German Federal Patent Court, ibid., 1023. For case comments, see Senftleben (2010), pp. 102-104, Assaf (2009), p. 5, Ohly (2008), 203, Klinkert and Schwab (1999), p. 1067 and Nordemann (1997), p. 389 .

51 German Federal Patent Court, ibid., 1023.
} 
The basic requirement of distinctiveness is not the only feature of trade mark law that is often presented as a sufficient safeguard against undesirable copyright/trade mark overlaps. While the requirement of distinctiveness fulfils a gatekeeper function and has the potential to prevent the acquisition of trade mark rights as long as it is not overcome through use in trade, ${ }^{52}$ other checks and balances in trade mark law concern the infringement criteria and the catalogue of limitations of the exclusive rights enjoyed by the trade mark owner.

\subsection{No Confusion Because of Cultural Significance}

In the context of the infringement analysis, a sign's cultural significance can tip the scales against a finding of a likelihood of confusion. This became apparent in Picasso/Picaro where the CJEU had to decide on an opposition against Daimler's application for registration of the sign PICARO for vehicles. The opposition had been lodged by the Picasso estate arguing that PICARO was likely to cause confusion with the earlier word mark PICASSO, which it had registered for various goods, including vehicles. ${ }^{53}$ Discussing the criteria for a finding of a likelihood of confusion in this context, the CJEU confirmed the first instance decision that in this particular case, conceptual differences between the PICASSO mark and the PICARO sign counteracted the low degree of visual and phonetic similarity. ${ }^{54}$ Conceptual differences could have this mitigating effect in cases where the meaning of at least one of the two signs was "clear and specific" so that the relevant public could grasp it immediately. ${ }^{55}$ As to the meaning of the PICASSO mark, the CJEU recalled the factual assessment of the first instance court which had found that

confronted with the word sign PICASSO, the relevant public inevitably sees in it a reference to the painter and that, given the painter's renown with that public, that particularly rich conceptual reference is such as greatly to reduce the resonance with which, in this case, the sign is endowed as a mark, among others, of motor vehicles. 56

Hence, the fact that the name "Picasso" is well known as a reference to the famous painter does not imply that the trade mark PICASSO is highly distinctive and enjoys broad protection against confusion. ${ }^{57}$ The painter's fame cannot simply be transferred to the trade mark as an identifier of commercial source. By contrast, the well-known cultural meaning of the sign reduces the risk of confusion because its immediate impact on the perception of the public may outweigh visual and/or aural similarities. A sign with a strong cultural connotation may thus constitute a weak trade mark. In such a case, the scope of trade mark protection will remain

\footnotetext{
52 Article 3(3) former Trade Mark Directive 2008/95; Art. 4(4) new Trade Mark Directive 2015/2436.

53 CJEU, 12 January 2006, case C-361/04P, Picasso/Picaro, paras. 5-6.

54 CJEU, ibid., para. 20.

55 CJEU, ibid., para. 20.

56 CJEU, ibid., para. 27.

57 As to the rejection of this counterargument advanced by the Picasso estate, see CJEU, ibid., paras. 11 and 32 .
} 
limited until use of the sign as a trade mark also becomes known to such an extent that the commercial function of indicating the origin of goods and services becomes strong enough to play an independent role besides the sign's original cultural meaning. 58

\subsection{Limitations Supporting Freedom of Expression}

Considering the statutory limitations of trade mark rights, it is finally to be conceded that even if prima facie infringement is found, use of trade-marked cultural material may still be found permissible in the light of the defences of "due cause" 59 or "referential use". 60 The case Lila Postkarte of the German Federal Supreme Court, for example, concerned the marketing of postcards that alluded ironically to trade marks and advertising campaigns of the chocolate producer Milka. ${ }^{61}$ On purple background corresponding to Milka's abstract colour mark, the postcard sought to ridicule the nature idyll with cows and mountains that is evoked in Milka advertising. ${ }^{62}$ It showed the following poem attributed to "Rainer Maria Milka": "Über allen Wipfeln ist Ruh/irgendwo blökt eine Kuh/Muh!"63

Assessing this ironic play with Milka's insignia, the Supreme Court held that for the use of Milka trade marks to constitute relevant trade mark use in the sense of Art. 5(2) of the former Trade Mark Directive 2008/95, it was sufficient that the postcard called to mind the well-known Milka signs. ${ }^{64}$ Even though being decorative, the use in question therefore gave rise to the question of trade mark infringement. ${ }^{65}$ Accordingly, the German Federal Supreme Court embarked on a scrutiny of the trade mark parody in the light of the infringement criteria of detriment to distinctive character or repute, and the taking of unfair advantage. ${ }^{66}$ Weighing Milka's concerns about a disparagement of the trade marks against the fundamental guarantee of the freedom of art, however, the Court finally concluded that the freedom of art had to prevail in the light of the ironic statement made with the postcard. ${ }^{67}$ The use of Milka trade marks was thus found to have taken place with "due cause" in the sense of Art. 5(2). ${ }^{68}$

\footnotetext{
58 With regard to examples of cases where this occurred, see Assaf (2009), pp. 2-3 and Senftleben (2010), pp. 101-102.

59 Article 5(2) former Trade Mark Directive 2008/95; Art. 10(2)(c) new Trade Mark Directive $2015 / 2436$.

60 Article 14(1)(c) new Trade Mark Directive 2015/2436.

61 German Federal Supreme Court, 3 February 2005, case I ZR 159/02, "Lila Postkarte", in: Gewerblicher Rechtsschutz und Urheberrecht 2005, p. 583.

62 German Federal Supreme Court, ibid., p. 583.

63 "It is calm above the tree tops, somewhere a cow is bellowing. Moo!" The attribution to 'Rainer Maria Rilke' is an allusion to the famous German writer Rainer Maria Rilke. See German Federal Supreme Court, ibid., p. 583.

64 German Federal Supreme Court, ibid., p. 584.

65 German Federal Supreme Court, ibid., pp. 584-585.

66 German Federal Supreme Court, ibid., pp. 584-585.

67 German Federal Supreme Court, ibid., pp. 584-585.

68 German Federal Supreme Court, ibid., p. 585.
} 
Similar decisions may follow from the application of the defence of "referential use" which was broadened in the framework of the EU trade mark law reform and is now laid down in Art. 14(1)(c) of the new Trade Mark Directive 2015/2436. ${ }^{69}$ As the decision Lila Postkarte shows, the requirement of "use as a trade mark" is applied flexibly in the EU. It does not serve as a filter to exclude, from the outset, all instances where the trade mark is not used in the traditional manner, i.e., to indicate the commercial source of the user's own goods or services. ${ }^{70}$ Instead, a mere reference to the trade mark $^{71}$ and a mere link with goods or services may be sufficient to trigger an infringement action. ${ }^{72}$ In the light of the elastic standard developed by the CJEU, even decorative use of a trade mark may amount to actionable trade mark use. ${ }^{73}$ Evidently, this development is worrisome from the perspective of cultural follow-on innovation. To exclude a trade mark action in cases of remix or reuse of trade-marked cultural symbols in the artistic domain, it is no longer sufficient to argue that the use takes place in a cultural context and, from the outset, does not constitute use "as a trade mark". The moment the use establishes a link with a trade-marked cultural symbol, this defence strategy may already fail.

If a reference to a trade-marked cultural symbol is qualified as actionable use "as a trade mark", however, the broadened defence of referential use offers the unauthorized user the opportunity to argue that the reference to the trade mark is the result of an honest practice of using the sign. In the case of use in the cultural domain, this line of reasoning finds support in Recital 27 of the new Trade Mark Directive 2015/2436 which explicitly states that "[u]se of a trade mark by third parties for the purpose of artistic expression should be considered as being fair as long as it is at the same time in accordance with honest practices in industrial and commercial matters."

The referential use defence is thus intended to serve as a final resort in cases where a conflict between trade mark rights and artistic freedom of expression arises. $^{74}$ Infringement claims following the registration of cultural heritage material

\footnotetext{
69 As to the considerations underlying this legislative change, see Kur and Senftleben (2017), para. 6.39-6.41

70 This stricter test, however, was mentioned with regard to the traditional identification function of trade marks in CJEU, 25 January 2007, case C-48/05, Adam Opel/Autec, para. 24.

71 CJEU, 23 October 2003, case C-408/01, Adidas/Fitnessworld, para. 39; CJEU, 10 April 2008, case C-102/07, Adidas/Marca, para. 41.

72 CJEU, 11 September 2007, case C-17/06, Céline, paras. 21-23; CJEU, 19 February 2009, case C-62/08, UDV/Brandtraders, para. 47. The emphasis on the criterion of a mere link with the goods or services offered under a conflicting sign was confirmed in cases dealing with keyword advertising. See CJEU, 23 March 2010, cases C-236/08-238/08, Google/Louis Vuitton et al., para. 72; 12 July 2011, case C-324/09, L'Oréal/ eBay, para. 92. For a discussion of this development, see Senftleben (2013b), pp. 147-148.

73 See CJEU, 23 October 2003, case C-408/01, Adidas/Fitnessworld, para. 39-41, where the Court established an ambiguous test by holding that "the fact that a sign is viewed as an embellishment by the relevant section of the public is not, in itself, an obstacle to the protection conferred by Article 5(2) of the Directive where the degree of similarity is none the less such that the relevant section of the public establishes a link between the sign and the mark." For decisions illustrating the weakness of the descriptive use defence in this context, see CJEU, 10 April 2008, case C-102/07, Adidas/Marca, paras. 47-49; CJEU, 25 January 2007, case C-48/05, Adam Opel/Autec, para. 44; German Federal Supreme Court, 24 November 2011, case I ZR 175/09, “Medusa", paras. 19-20.

74 For a more detailed discussion of this point, see Schovsbo (2018).
} 
as a trade mark will thus fail if use of the trade-marked material for the purposes of remix and reuse in the cultural domain is deemed permissible under Art. 14(1)(c).

\section{Critique}

At first glance, the described checks and balances in trade mark law - the registration requirement of distinctiveness, the impact of cultural significance on the infringement analysis and the defences of due cause and referential use - may appear sufficiently robust to dispel concerns about a corrosive effect of cultural heritage trade marks on freedom of expression in the cultural domain.

However, a closer look at these safeguards reveals how volatile they are. It also shows the core problem underlying the debate: the traditional acceptance of trade mark rights relating to cultural material is based on an understanding of trade marks as source identifiers and trade mark rights as tools to ensure market transparency. After the remarkable broadening of the concept of "use as a trade mark" in the jurisprudence of the $\mathrm{CJEU}^{75}$ and the explicit recognition of advertising, investment and communication functions as independent protection objectives, ${ }^{76}$ this traditional understanding no longer corresponds with the current scope and reach of trade mark rights.

It is no longer sufficient that the public does not perceive use in the cultural domain as an indication of commercial origin. Instead, use for cultural purposes may be qualified as actionable use in the sense of trade mark law even if it merely refers to a protected mark. ${ }^{77}$ As a result, the exercise of artistic freedom of expression requires the invocation of defences against infringement claims which, in turn, enhances the legal uncertainty surrounding unauthorized use and may have a deterrent effect on cultural follow-on innovation. With the evolution of trade mark rights of current proportions, the hypothesis of non-interference with artistic creativity has become doubtful.

\subsection{Registration Requirement of Distinctiveness}

In the Mona Lisa case, the German Federal Patent Court relied on the basic requirement of distinctive character and saw no need to invoke public policy and accepted principles of morality as further grounds for refusal. This focus on distinctiveness as sole gatekeeper has far-reaching consequences. The exclusion of the Mona Lisa registration because of a lack of distinctive character following from the painting's widespread use in advertising is weak because non-distinctive, descriptive and generic signs can acquire the requisite distinctive character as a result of use in trade. ${ }^{78}$ The decision of the German Federal Patent Court thus offers

\footnotetext{
75 For a more detailed discussion of this development, see Kur and Senftleben (2017), para. 5.14-5.15 and 5.49-5.56.

76 CJEU, 18 June 2009, case C-487/07, L'Oréal/Bellure, para. 58. Cf. Kur and Senftleben (2017), para. $1.12-1.39$.

77 Cf. Kur and Senftleben (2017), para. 5.50-5.56; Derclaye and Leistner (2011), p. 328.

78 Article 3(3) former Trade Mark Directive 2008/95; Art. 4(4) new Trade Mark Directive 2015/2436.
} 
the chance of overcoming the registration obstacle through intensive use in product marketing and advertising. Once consumers have been taught to perceive the Mona Lisa as a source identifier referring to the trade mark applicant, a registration of the famous painting becomes possible. ${ }^{79}$

Viewed from this perspective, the Mona Lisa decision is unsatisfactory. While the German Federal Patent Court may have felt that the distinctiveness test is sufficient to keep signs with cultural significance free from trade mark protection, the reliance on the basic protection requirement may have the opposite effect. Enterprises may regard the prospect of acquiring trade mark rights as a result of use in trade as an invitation to invest in marketing and advertising activities based on cultural signs. They may strive to make a particular cultural heritage symbol part of the trade mark experience they are offering to consumers. The mere possibility of acquiring trade mark rights in consequence of use in trade may be sufficient to support business activities that lead to the removal of cultural material from the public domain instead of putting an end to attempts to obtain trade mark rights to cultural creations. ${ }^{80}$

This risk must not be underestimated. Literary or artistic works in the public domain, such as Vigeland's creations, have rich and positive connotations. Investing in the acquisition of trade mark rights in such a work, an enterprise can benefit from the favourable image which the cultural material already has. Given the popularity of the sign, the process of brand image creation, as already indicated above, need not be started from scratch. The establishment of a link with the cultural work offers the chance of an image transfer that may outweigh the costs of advertising necessary to acquire distinctiveness through use in trade. The enhanced value to be gained once trade mark protection is acquired may allow bigger investments than in regular cases of brand development - investments capable of setting aside the cultural renown and "particularly rich conceptual reference" which the CJEU qualified as an obstacle to a strong distinctive character in Picasso/Picaro. ${ }^{81}$

Against this background, it is of particular interest that in the Vigeland case, the Municipality of Oslo emphasized its continuous efforts and investments seeking to make Vigeland's works "well known and valuable". ${ }^{82}$ Even though the Municipality is not a private business, it developed a line of argument that could serve as a model for companies seeking to acquire trade mark rights in "their" preferred cultural heritage symbol. The underlying logic is simple: as substantial investment and marketing efforts have taken place, the cultural sign concerned is due to the investor. The requirement of distinctive character is incapable of preventing the evolution of this rights acquisition strategy.

\footnotetext{
${ }^{79}$ For a detailed discussion of this conditional character of a refusal based on a lack of distinctiveness, see Senftleben (2013a), pp. 783-784 and Anemaet (2016), p. 303.

${ }^{80}$ Cf. Anemaet (2016), pp. 331-332 and Senftleben (2013a), pp. 812-813; Ramsey (2003), p. 1150 and Denicola (1982), p. 170. See also the ECS (2017), pp. 460-461.

${ }^{81}$ CJEU, 12 January 2006, case C-361/04P, Picasso/Picaro, para. 27. Cf. Wandtke and Bullinger (1997), p. 578.

${ }^{82}$ Report for the Hearing, Judge-Rapporteur Baudenbacher, 5 October 2016, case E-5/16, Municipality of Oslo ("Vigeland"), para. 32.
} 
In addition, it must be considered that the requirement of distinctiveness as a basic threshold for the acquisition of trade mark rights fails to cover the entire spectrum of cultural public domain material. The Mona Lisa case concerned a famous cultural symbol belonging to mankind's universal cultural heritage. In the light of the popularity of the painting and its widespread use in advertising, the Court could reject the registration attempt on the grounds that the sign had become a customary marketing tool and constituted a non-distinctive, generic sign. In the case of cultural material that is not well known, this line of argument is not available. ${ }^{83}$ For example, the registration of a culturally important, but not widely known melody taken from a piece of classical music could hardly be rejected based on the argument that the sign has been used so frequently in a commercial context that consumers are unlikely to perceive it as a reference to an individual commercial source. ${ }^{84}$ By contrast, even the assumption of inherent distinctiveness seems inescapable when use of the melody for marketing purposes is new for the consuming public. Once an exclusive link between the sign and an individual commercial source is established in the minds of consumers, it makes no difference from a trade mark perspective whether an enterprise develops its own melody for advertising purposes or uses a pre-existing melody taken from the classical public domain repertoire.

Moreover, a finding of inherent distinctive character may follow from use in a context that creates a contrast with the genuine meaning of a cultural symbol. For example, the requirement of distinctive character can hardly be invoked against an applicant seeking to register a detail of Pablo Picasso's painting "Guernica" in respect of weapons and other "defence" technology and services. By contrast, applicable trade mark standards offer room for arguing that the public would be able to identify a company's goods and services in this category on the basis of a sign derived from the Picasso painting.

Considering these weaknesses of the requirement of distinctive character as a safeguard against the re-appropriation of cultural material in the public domain, court and office decisions denying trade mark rights on the ground that the requisite distinctive character is missing must not hide the fact that trade mark law fails to provide cultural grounds for refusal that would allow courts and offices to name the true reason for not awarding trade mark rights. It would be desirable to have room in trade mark law to articulate prevailing cultural concerns candidly, in particular the risk of encouraging the privatization of parts of the cultural heritage, the undesirable redefinition of important cultural expressions in commercial contexts, and unfair free-riding on the status, reputation and favourable image of cultural creations. ${ }^{85}$

\footnotetext{
83 See Klinkert and Schwab (1999), p. 1068, who express similar concerns. Cf. Senfteben 2010, pp. 103-104.

84 Examples of this kind are not of a theoretical nature. In Germany, for instance, the beer producer Licher has consistently used "Solveig's Song" from Edvard Grieg's Peer Gynt Suite in advertising since the 1990 s. See https://www.youtube.com/watch?v=dfGGjk1QEeM.

85 Wandtke and Bullinger (1997), p. 578 and Senftleben (2010), pp. 103-104. For a solution based on public order/morality considerations, see Klinkert and Schwab (1999), p. 1073, Van Woensel (2007), pp. 412-413, Osenberg (1996), pp. 102-103 and Nordemann (1997), p. 391. See also the critique expressed by Ohly (2008), p. 207; Seifert (2000), p. 1018.
} 
In comparison with these clear articulations of cultural reasons for denying trade mark protection, the argument of a lack of distinctive character misses the point. In the Mona Lisa case, the German Federal Patent Court rightly pointed out that the famous painting was used frequently in marketing and advertising contexts. Therefore, the Court had reason to assume widespread use by various enterprises and a lack of distinctive character. From a cultural perspective, however, it is cynical to solve the case on this basis. On its merits, the Court argued that the Mona Lisa could escape registration as a trade mark because commercial use of this cultural symbol had already become commonplace. The registration as a trade mark is rejected because other traders may want to use the cultural symbol in their advertising as well. However, the Court saw no reason to deny the trade mark registration because free-riding on the sign's reputation and positive image, the attachment of commercial connotations, the blurring of the sign's genuine cultural meaning and the sign's exposure to commercial marketing strategies were inacceptable. $^{86}$

In sum, the application of the basic requirement of distinctive character is thus unsatisfactory. It is unreliable because a lack of distinctiveness can be overcome through use in trade. In the case of relatively unknown cultural material, it may fail to serve as a safeguard against the acquisition of trade mark rights altogether. The assumption of inherent distinctive character may be inescapable when unknown literary or artistic works are introduced as new source identifiers in trade. Finally, the exclusion of cultural material from trade mark protection on the basis of the requirement of distinctive character also prevents courts and trade mark offices from clearly articulating prevailing cultural interests and concerns. Instead, they must keep within the assessment standards offered by the test of distinctiveness, such as widespread use in a commercial context implying a non-distinctive, descriptive or generic character, or a need to keep the sign free for other traders who may want to use the cultural symbol in advertising and product marketing as well. Given these shortcomings, the problem of an undesirable re-appropriation of cultural public domain material by virtue of trade mark law cannot be solved on the basis of the requirement of distinctive character. It would be desirable to have more effective tools to avoid the acquisition of trade mark rights. ${ }^{87}$

\subsection{Impact of Cultural Significance on Infringement Analysis}

In Picasso/Picaro, the CJEU held that the renown of a cultural creation may constitute such a rich conceptual reference that it greatly reduces the recognition of the sign as a trade mark. ${ }^{88}$ Hence, it seems that in the Court's view, cultural significance is a factor weighing against the assumption of a highly distinctive

\footnotetext{
86 Assaf (2009), p. 5.

87 Anemaet (2016), pp. 331-332, Calboli (2014a), p. 34, Calboli (2014b), pp. 76-78 and Senftleben (2013a), pp. 816-817 and 823-825. For an example of an outright exclusion (based on functionality considerations) putting an end to further attempts to acquire trade mark rights, see German Federal Patent Court, 26 September 2001, case 28 W (pat) 61/01, "Schmuckring". Cf. the discussion of this case and its practical effect by Kur (2011), p. 12.
}

88 CJEU, 12 January 2006, case C-361/04P, Picasso/Picaro, para. 27. 
character. This, in turn, is a factor weighing against broad protection against confusion and excluding protection against dilution.

Nonetheless, it would be wrong to jump to the conclusion that trade mark rights relating to cultural signs are generally unproblematic because the scope of protection against confusion and dilution will always remain limited. By contrast, the elasticity of distinctive character as a parameter for determining the scope of protection must be factored into the equation. In the Vigeland case, the statements submitted by the Municipality of Oslo show clearly that the city is confident to have invested enough to establish the works of the famous sculptor as strong source identifiers. ${ }^{89}$ In fact, a relatively weak trade mark may be developed into a powerful brand over time. This is inherent in the configuration of trade mark law. In addition, the acquisition of a considerable degree of distinctive character and a broad scope of trade mark protection does not seem particularly difficult when a trade mark consists of a sign that has cultural significance but is not widely known among the consuming public. A symbol, shape or melody stemming from a culturally important but relatively unknown work is unlikely to have a strong cultural connotation capable of weakening the recognition of the sign as an indication of commercial origin. Who thinks of Nike, the Greek goddess of victory, when seeing the trade mark NIKE? ${ }^{90}$ Who is aware of culturally important signs of indigenous communities?

Given the relatively low threshold for acquiring anti-dilution protection in the EU, there is also a substantial risk of unknown signs with cultural significance becoming eligible for enhanced protection against dilution. In contrast to other trade mark systems requiring recognition among the general consuming public, niche reputation is sufficient under EU trade mark law. ${ }^{91}$ For a trade mark to constitute a mark with a reputation, it must be known by the target group of the goods or services marketed under the trade mark. In the case of specific products, this target group may be a specialized public, such as traders in a specific sector. The required degree of knowledge is reached when the mark is known by a significant part of the relevant public. $^{92}$

Once reputation is established, EU trade mark law offers anti-dilution protection covering blurring, tarnishment and unfair free-riding in competitive and noncompetitive situations. ${ }^{93}$ The evidence to be produced need not necessarily include

\footnotetext{
${ }^{89}$ Report for the Hearing, Judge-Rapporteur Baudenbacher, 5 October 2016, case E-5/16, Municipality of Oslo ("Vigeland"), para. 32.

${ }^{90}$ With regard to these and further examples, see Assaf (2009), pp. 2-3 and Senftleben (2010), pp. 101-102.

${ }^{91} C f$. Senftleben (2009), pp. 50-55, McCarthy (2004), p. 1163 and Beebe (2006), p. 1157.

92 CJEU, 14 September 1999, case C-375/97, General Motors/Yplon, paras. 24 and 26. In respect of the territorial expansion required, see CJEU, ibid., para. 28; CJEU, 6 October 2009, case C-301/07, Pago/ Lattella, para. 29.

${ }^{93}$ Under the former Trade Mark Directive 2008/95, this followed from CJEU, 9 January 2003, case C-292/00, Davidoff/Gofkid. It has been made explicit in Art. 10(2)(c) new Trade Mark Directive 2015/2436. As to the scope of protection offered in cases of marks having a reputation, see particularly CJEU, 18 June 2009, case C-487/07, L'Oréal/Bellure, and the comments by Senftleben (2011a), p. 383; Ohly (2009), pp. 711-712.
} 
proof of a change in the economic behaviour of consumers. ${ }^{94}$ For a claim based on the taking of unfair advantage, it suffices to argue that "a third party attempts, through the use of a sign similar to a mark with a reputation, to ride on the coat-tails of that mark." ${ }^{95}$ Moreover, the CJEU refuses to consider the need to keep protected signs freely available in the context of the infringement analysis. In Adidas/Marca, the Court explained that it was clear that the requirement of availability was "extraneous both to the assessment of the degree of similarity between the mark with a reputation and the sign used by the third party and to the link which may be made by the relevant public between that mark and the sign." 96

In addition to these developments in the field of specific infringement criteria, current EU trade mark law is an example of an advanced trade mark system in which inherent limits of exclusive rights, such as the requirements of "use in the course of trade" and "use in relation to goods or services" have lost much of their potential to contain access to trade mark protection from the outset. As already indicated above, the requirement of use in relation to goods or services is applied flexibly by the CJEU. In principle, this general prerequisite for obtaining protection could be applied to confine the scope of trade mark rights to instances where the senior user's trade mark is employed by a junior user as an identifier of commercial source with regard to its own goods or services. Following this approach, the requirement of trade mark use could serve as a filter to exclude claims that are unrelated to the identification and distinction of goods and services from the outset. Considerable breathing space for freedom of use in a cultural context could be created in this way. ${ }^{97}$

However, the CJEU takes the opposite approach, weakening the trade mark use requirement instead of sharpening its conceptual contours. As explained, the Court even expressed the view that, for satisfying the requirement of trade mark use, it was sufficient that a mere link was established with the trade mark. ${ }^{98}$ In consequence,

\footnotetext{
94 This test applies in cases of blurring and tarnishment. See CJEU, 27 November 2008, case C-252/07, Intel/CPM, para. 77; CJEU, 14 November 2013, case C-383/12 P, Environmental Manufacturing/OHIM, para. 37. Cf. Kur and Senftleben (2017), para. 5.223-5.228; Bouvel (2010), 123, Quaedvlieg (2009a), 253, Quaedvlieg (2009b), p. 799 and Middlemiss and Warner (2009), pp. 331-332.

95 CJEU, 18 June 2009, case C-487/07, L'Oréal/Bellure, para. 49. For a critical comment on intuitive protection against free-riding as a species of unjust enrichment law, see Lemley and McKenna 2010, p. 137.

96 CJEU, 10 April 2008, case C-102/07, Adidas/Marca, para. 43.

97 For a discussion of the concept of trade mark use in EU trade mark law, see Kur and Senftleben (2017), para. 5.14-5.15 and 5.49-5.56; Kur (2008), p. 11; Yap (2009), pp. 331-87; Simon Fhima (2005), p. 401; Loughlan (2000), p. 328. As to the recognition of a potential gatekeeper function of the trade mark use requirement in US and EU law, see Senftleben (2011b), p. 39; Dogan and Lemley (2008), p. 542: "By maintaining the law's focus on misleading branding, the trademark use doctrine keeps trademark law true to its ultimate goal of promoting competitive markets." However, see also Dinwoodie and Janis (2007), p. 773, p. 773. 1657-1658, who doubt that problems arising in the current "expansionist climate" could be solved by recalibrating the notion of trade mark use: "Trademark use is simply too blunt a concept, no matter how defined, to capture the full range of values at play in these debates." For a summary of the debate, see Davison and Di Giantomasso (2009), p. 443; McKenna (2009), p. 773. For a fundamental critique of the continuous expansion seeking to reduce the scope of trade mark protection to the traditional origin function, see moreover Peukert (2012), pp. 96-107.

98 CJEU, 23 October 2003, case C-408/01, Adidas/Fitnessworld, para. 39; German Federal Supreme Court, 3 February 2005, case I ZR 159/02, "Lila Postkarte", in: Gewerblicher Rechtsschutz und Urheberrecht 2005, pp. 583 (584-585).
} 
the purported threshold of establishing trade mark use does not prevent trade mark owners from successfully pursuing third-party uses that are not - and are not intended to be - perceived as indications of commercial source. On the contrary, referential use is brought within the reach of the exclusive rights of trade mark owners. $^{99}$ The impact of this broad concept on use for cultural purposes is considerable. As described above, even decorative use that merely calls to mind the protected trade mark may give rise to an infringement action.

Surveying these developments, it can be said that the inherent limits of exclusive trade mark rights - use in the course of trade, use as a trade mark, use likely to cause confusion and use likely to cause dilution - have become elastic and unreliable safeguards of freedom of use for cultural purposes. In many cases of use in a cultural context, it will be difficult to rule out the threat of a trade mark claim on the basis of these infringement criteria. ${ }^{100}$ For example, it is inaccurate to assume that trade mark rights will hardly ever affect use in a cultural context because this type of use is unlikely to constitute use in the course of trade. Cultural activities require not only freedom to create new works on the basis of pre-existing material, but also freedom to bring these new works to the attention of the public and create a market for them. It is recognized in the context of the fundamental guarantee of artistic freedom of expression that sufficient room must be offered not only for art creation but also for art marketing. In Germany, for instance, it is established case law of the Federal Constitutional Court that the freedom of art "protects a cultural activity as such ('Werkbereich') but, in addition, also the performance and distribution of the artwork which is necessary for the public's encounter with art ('Wirkbereich')."101

Hence, it would be wrong to confine the debate on a potential impediment of use in a cultural context to the process of creation. It is not sufficient that an artist enjoys the freedom of using trade-marked material in her atelier. The guarantee of freedom of expression and freedom of art also requires freedom to sell and promote an artwork. As with other inherent limits of trade mark rights, the basic infringement criteria of "use in the course of trade" and "use in relation to goods or services", therefore, do not constitute safeguards that are strong enough to declare trade mark rights to cultural signs unproblematic.

\subsection{Limitations of Trade Mark Rights Insufficient}

This finding gives rise to the question whether the defences in EU trade mark law are sufficient to eliminate the risk of a corrosive effect on artistic expression. The amended EU trade mark legislation explicitly refers to freedom of expression as a guiding principle in Recital 27 of the new Trade Mark Directive 2015/2436. The fundamental guarantee of freedom of expression, however, is unlikely to prevent trade mark owners from bringing a claim. The Dutch case Darfurnica can serve as an example of a particularly aggressive enforcement strategy that included actions

\footnotetext{
99 Cf. Kur and Senftleben (2017), para. 5.50-5.54; Derclaye and Leistner (2011), p. 328.

100 Cf. Calboli (2014b), pp. 52-54.

101 German Federal Constitutional Court, 31 May 2016, case 1 BvR 1585/13, "Metall auf Metall”, para. 68.
} 
against use in the cultural domain. In this case, Louis Vuitton sued the painter Nadia Plesner for infringement of industrial design rights relating to a Louis Vuitton handbag. Nadia Plesner had included a poor black boy holding a Louis Vuitton handbag in her painting "Darfurnica". Despite the artistic context of the use, Louis Vuitton did not refrain from the infringement action. ${ }^{102}$ Before the The Hague District Court, Nadia Plesner finally prevailed. The court deemed her use permissible in the light of the guarantee of artistic freedom of expression. Nonetheless, the case shows that the guarantee of freedom of expression does not eliminate the risk of infringement claims.

This remaining risk - and the legal uncertainty arising from a potential lawsuit distinguishes the scenario in which a sign with cultural significance is in the public domain, from the situation where the sign is re-appropriated as a result of a trade mark registration. Once cultural heritage signs are registered, the scope of trade mark protection creates considerable legal uncertainty. Given the described elasticity of infringement criteria in modern trade mark law, the risk of infringement can no longer be ruled out. This legal uncertainty is likely to have a deterrent effect on cultural follow-on innovation even if the artist can rely on the defence of "due cause" or "referential use". These defences merely add a further discussion point to the list of legal arguments. The claimant will assert that the use at issue is excessive and falls outside the scope of any defence. The defendant will seek to convince the court that the defence is fully applicable.

In various areas of creative activity, concerns have been articulated about a growing fear of artists to be sued for intellectual property infringement because of the reuse of pre-existing cultural material that still enjoys protection. ${ }^{103}$ These fears can have a chilling effect on creativity and cultural diversity. An artist seeking to avoid potential lawsuits will refrain from the creation of works based on preexisting material or limit takings from pre-existing material to an absolute minimum. ${ }^{104}$ Therefore, the legal uncertainty arising from the elastic application of trade mark infringement criteria in the jurisprudence of the CJEU leads to a climate that is not conducive to new cultural productions. Instead, it is likely to impoverish new cultural productions in terms of creative inputs.

In the above-described case Lila Postkarte, the defence of "due cause" finally saved the artistic play with the Milka insignia. However, the fact remains that even though the use was found to constitute use in an artistic context - the elastic concept of use as a trade mark developed by the CJEU prevented a judgment that put an end to the infringement action at an early stage. ${ }^{105}$ The Court did not hold

\footnotetext{
102 The Hague District Court, 4 May 2011, case LJN BQ3525, Nadia Plesner/Louis Vuitton. For a case comment, see Visser (2011), pp. 740-742.

103 Sakulin (2010), pp. 292-293; McGeveran (2008), pp. 1206-1207 and 1224-1225; Hofrichter (2007), p. 1926; Gibson (2007), p. 913; Cohen (2006), p. 156; Aufderheide and Jaszi (2004), pp. 29-30; Lessig (2004), pp. 185-188.

104 Banerjee (2012), p. 564; Morrison (2008), pp. 131-136; Hofrichter (2007), p. 1926; Cohen (2006), pp. 154-156; Amabile (1996), pp. 115-120 and 231-232.

105 As to the importance to provide mechanisms that, in cases involving artistic freedom of expression, prevent lengthy lawsuits from the outset, see McGeveran (2008), pp. 1224-1225; Lessig (2004), pp. $185-188$.
} 
that the use did not constitute actionable trade mark use from the outset. Instead, the parodist had to invoke the defence of due cause and argue the case in several instances until the German Federal Supreme Court took a final decision. The artistic use at issue thus led to a complex lawsuit - even though the Milka trade marks had not been used as identifiers of commercial source.

In many cases, artists will not have sufficient confidence and financial resources to take the risk of a lengthy lawsuit. If the Municipality of Oslo sends a cease-anddesist letter stating that a given form of using Vigeland's works amounts to trade mark infringement, this will often suffice to put an end to the use in a cultural context. ${ }^{106}$ Discussing the constitutional guarantee of artistic freedom of expression, the deterrent effect that arises from legal uncertainty surrounding a permitted use of protected material has explicitly been recognized by the German Federal Constitutional Court (the Supreme Court in matters of constitutional law) in Metall auf Metall. The decision was triggered by the jurisprudence which the German Federal Supreme Court (the Supreme Court in matters of civil law) had developed with regard to sound sampling. The underlying lawsuit had been brought by the iconic German electronic music pioneers Kraftwerk. They asserted copyright and phonogram producer rights against the unauthorized use of a rhythmic sound fragment of two seconds which served as the basis of a continuous rhythmic sequence in Sabrina Setlur's song "Nur mir". The sound fragment stemmed from the piece "Metall auf Metall” in Kraftwerk's 1977 album Trans Europa Express.

In its earlier decisions in the Metall auf Metall saga, ${ }^{107}$ the German Federal Supreme Court had held that sound sampling fell outside the scope of permitted free use and amounted to infringement of the neighbouring right of the phonogram producer if the unauthorized user was capable of producing the desired sound fragment himself. ${ }^{108}$ In a further decision, the Court had specified that this criterion required an assessment of whether a sound producer with average equipment and talent, at the time of unauthorized use, would have been capable of producing an own recording which, from the perspective of the target audience, could be qualified as equal to the original sound fragment. ${ }^{109}$

The German Federal Constitutional Court found that this assessment criterion encroached upon the guarantee of free artistic expression because it created too much legal uncertainty. The Court expressed the fear that

even in cases where the production of an equal recording is not possible, artistic creators may refrain from use - which, in this case, would be permissible in the opinion of the German Federal Supreme Court - because

\footnotetext{
${ }^{106}$ For a more detailed discussion of the chilling effect of cease-and-desist strategies, see Calboli (2014a), pp. 31-32; McGeveran (2008), pp. 1206-1207; Lessig (2004), pp. 185-188.

${ }^{107}$ For a more detailed discussion of the Metall auf Metall decisions in Germany, see Podszun (2016), pp. 606-612; Leistner (2016), pp. 772-777; Schippers (2014), p. 105; Conley and Braegelmann (2009), p. 1017; Dougherty (2007), p. 481.

${ }^{108}$ German Federal Supreme Court, 20 November 2008, case I ZR 112/06, "Metall auf Metall I", p. 15, published in: Gewerblicher Rechtsschutz und Urheberrecht 2009, p. 403.

109 German Federal Supreme Court, 13 December 2012, case I ZR 182/11, “Metall auf Metall II", p. 16, published in: Gewerblicher Rechtsschutz und Urheberrecht 2013, p. 614.
} 
the effort necessary to provide evidence of missing own production options and the legal risk appear too big. The criterion based on the feasibility of producing an equal sound thus has a deterrent effect which requires a particularly efficient control in the light of constitutional law. ${ }^{110}$

Hence, the deterrent effect that arises from legal uncertainty surrounding a permitted use must be factored into the equation. With regard to the attempt to reappropriate works created by Gustav Vigeland, this means that the legal uncertainty surrounding the invocation of available defences, such as "due cause" and "referential use", is relevant to the assessment. It is not sufficient that the statutory law provides for defences and that judges are willing to hear arguments based on these defences. It must also be considered whether artistic creators may nevertheless refrain from permissible use because the re-appropriation of an artwork as such leads to the acquisition of trade mark rights and involves the risk of an infringement action. Even if courts may finally manage to arrive at reasonable solutions in cases involving use of trade-marked cultural material, the fundamental difference remains that legal uncertainty about a potential trade mark claim is surrounding the use of cultural heritage material once it has been re-appropriated. The risk of potential trade mark infringement is hanging above use made of affected cultural creations like the sword of Damocles. From a cultural perspective, the scenario in which an artwork belongs to the public domain and is entirely free, is clearly preferable over a situation where trade mark rights are granted and artists are exposed to the risk of an infringement claim.

\section{The Vigeland Judgment of the EFTA Court}

Against this background, it seems advisable to strike at the root of the problem and pave the way for stricter access control that prevents the acquisition of trade mark rights to cultural heritage material from the outset. ${ }^{111}$ In this respect, the Vigeland decision of the EFTA Court is a milestone. The Court takes important steps in the right direction.

\subsection{Legal Status Definition of the Public Domain}

Firstly, it is noteworthy that the EFTA Court adheres to a legal status definition of the public domain: for a cultural creation to be part of the public domain, it must be unencumbered with intellectual property rights. ${ }^{112}$ This understanding of the public

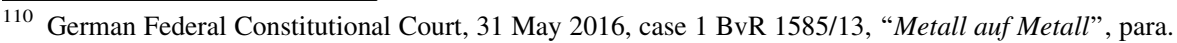
100.

${ }^{111}$ For a more detailed discussion of this point, see Anemaet (2016), pp. 331-332; Calboli (2014a), p. 34; Calboli (2014b), pp. 76-78; Senftleben (2013a), pp. 816-817 and 823-825. With regard to the field of traditional knowledge and traditional cultural expressions, see Frankel (2005), p. 83; Frankel (2008), p. 433, discussing the concept of "cultural offence" in New Zealand and a sui generis protection regime that would offer grounds for opposition under trade mark law.

${ }^{112}$ EFTA Court, ibid., para. 66. For an overview of the different definitions of the public domain, including more flexible approaches including well-established limitations of protection, see Senftleben (2013c), pp. 112-138; Samuelson (2006a), pp. 145-154; Samuelson (2006b), pp. 13-17.
} 
domain follows from the Court's assumption that the public domain status of cultural expressions is a corollary of the process of communicating literary and artistic works:

Once communicated, creative content belongs, as a matter of principle, to the public domain. In other words, the fact that works are part of the public domain is not a consequence of the lapse of copyright protection. Rather, protection is the exception to the rule that creative content becomes part of the public domain once communicated. ${ }^{113}$

From this perspective, the legal status of "absence of individual protection for, or exclusive rights to, a work" is the normal status of literary and artistic works and the period of copyright protection is an anomaly during which the work is withheld from a free and entirely open communication process. ${ }^{114}$ Precursors of this approach can be found in national law. The German Federal Supreme Court, for instance, also held that a work, once published, becomes an independent factor influencing the cultural and intellectual perception of its age which increasingly evaporates in the process of its communication until the time of protection finally expires. ${ }^{115}$

Importantly, the understanding of the public domain as "absence of individual protection for, or exclusive rights to, a work" implies that the public domain status cannot artificially be simulated by adopting robust defences in trade mark law. ${ }^{116}$ Even if trade mark law provides for use privileges that support the reuse and remixing of protected signs in the cultural domain, the fact remains that cultural heritage signs no longer belong to the public domain once they are encumbered with trade mark rights. The precondition of absence of protection is no longer fulfilled. ${ }^{117}$ To effectively preserve the public domain of literary and artistic works, it is thus necessary to ensure that trade mark protection is not granted in the first place.

\subsection{Rationales of Preserving the Public Domain}

The EFTA Court also clarifies the policy objectives that form the basis of its approach. In the Court's view, the determination of a fixed time frame of copyright protection after which anyone can draw from ideas and creative content of others without limitation serves the principles of legal certainty and protection of legitimate expectations. ${ }^{118}$ It also serves the general interest in "protecting creations of the mind from commercial greed" and "ensuring the freedom of the arts". 119

\footnotetext{
113 EFTA Court, 6 April 2017, case E-5/16, Municipality of Oslo ("Vigeland”), para. 66.

114 EFTA Court, ibid., para. 66.

115 Cf. Kreile (1993), pp. 257-258; Kirchhof (1988), pp. 34-35.

116 For an alternative approach, recognizing robust user freedoms as part of the public domain, see Benkler (1999), pp. 362-363. Even if this broader understanding of the public domain is adopted, however, the defences in trade mark law are not automatically sufficient safeguards. This is because the legal uncertainty surrounding their application, "due cause" and "referential use" do not constitute "easy cases" in the sense of Benkler's concept. See the discussion of legal uncertainty in the preceding section.

117 EFTA Court, 6 April 2017, case E-5/16, Municipality of Oslo ("Vigeland"), para. 71.

118 EFTA Court, ibid., para. 65.

119 EFTA Court, ibid., para. 65.
} 
These policy considerations are broader than the reasons given by the CJEU for policing the border between trade mark rights and patent or industrial design protection. The CJEU held that the shape exclusions in EU trade mark law served the purpose of ensuring undistorted, free competition. ${ }^{120}$ In comparison with this competition-based explanation of a dividing line between trade mark rights and other forms of intellectual property protection, the EFTA Court's reference to "commercial greed" and "freedom of the arts" adds important aspects. It includes the need to prevent the pursuit of profit maximization from suppressing the evolution of free, autonomous art. ${ }^{121}$ As a result, concerns about follow-on innovation in the artistic domain can be factored into the equation. The analysis need no longer be confined to competition-based considerations.

\subsection{Assessment of Preservation Tools}

The EFTA Court also recalls the remarkable development of EU trade mark protection in recent years: from a protection system that focuses on the protection of consumers against confusion of origin, to a protection regime that recognizes investment in brand development as an independent objective of protection. ${ }^{122}$ While explicitly referring to remaining differences in the configuration of copyright and trade mark protection, ${ }^{123}$ this modern understanding of the trade mark system leads to a clear articulation of the risk of wrong incentives for investment in cultural heritage grabbing: "The possibility of acquiring distinctiveness through use provided for in Article 3(3) of the Trade Mark Directive may lead undertakings, which seek to transfer the appeal of formerly copyright protected works to their goods or services, to try to appropriate the work through targeted marketing campaigns." 124

Therefore, the Court does not jump to the conclusion that trade mark protection can hardly ever have a corrosive effect on cultural follow-on innovation because trade marks are merely identifiers of commercial source. By contrast, the understanding of trade mark law as an incentive and investment scheme - and trade mark rights as brand exploitation instruments ${ }^{125}$ - yields the insight that the mere possibility of acquiring distinctiveness through use can lead to rights acquisition strategies that aim at the exploitation of positive cultural connotations which are attached to signs with cultural significance. The warning against

\footnotetext{
120 CJEU, 18 September 2014, case C-205/13, Hauck/Stokke, paras. 18-20. Cf. CJEU, 18 June 2002, case C-299/99, Philips/Remington, para.78; CJEU, 14 September 2010, case C-48/09 P, Lego/Mega Brands, para. 43. For a detailed discussion of this policy background, see Kur (2011), pp. 6-10.

121 For a theoretical underpinning of this concern about sufficient room for autonomous art, see Senftleben (2017), pp. 25-28 on the basis of the sociological analysis of processes of creation by Bourdieu (1992)/1999, pp. 103-105, 342-345 and 530-533.

122 EFTA Court, 6 April 2017, case E-5/16, Municipality of Oslo ("Vigeland"), para. 72. Cf. Kur and Senftleben (2017), para. 1.12-1.39.

123 EFTA Court, ibid., para. 62.

124 EFTA Court, ibid., para. 75. As to the risk of dysfunctional cumulation, see also ECS (2017), p. 458.

125 Cf. Senftleben (2009), pp. 46-50, with further references.
} 
"targeted marketing campaigns" corresponds with the Court's earlier reference to the need to protect cultural creations from "commercial greed". 126

This theoretical framework allows an adequate assessment of the potential of different grounds for refusal for preventing the re-appropriation of cultural heritage signs on the basis of trade mark law. Two questions are central to the Court's assessment: whether a ground for refusal can be overcome by demonstrating distinctiveness acquired through use in trade; and whether the ground for refusal is confined to specific goods or services. ${ }^{127}$

Viewed through the prism of these two parameters, it becomes clear that nondistinctiveness, descriptiveness and genericness are weak safeguards against the risk of re-privatizing the public domain. ${ }^{128}$ These grounds for refusal can be overcome through use in trade. Moreover, their scope is confined to specific goods or services. Not surprisingly, the EFTA Court concludes that Art. 3(1)(b)-(d) of the former Trade Mark Directive 2008/95 (Art. 4(1)(b)-(d) of the new Trade Mark Directive 2015/2436) do not ensure that "a particular sign is, in general, kept free for use. Thus, these provisions do not guarantee that the work remains within the public domain." 129

National decisions testify to the weakness of a refusal based on nondistinctiveness, descriptiveness or genericness when it comes to signs with cultural significance. The Marlene Dietrich decision of the German Federal Supreme Court can serve as an example. The case concerned an attempt to register a portrait photograph of the actress Marlene Dietrich as a trade mark in respect of photographs, posters, postcards and goods of a similar nature. In contrast to the Federal Patent Court, ${ }^{130}$ the German Federal Supreme Court saw no room for applying the exclusion of shapes resulting from the nature of the goods in this case. ${ }^{131}$ Instead, it relied on the requirement of distinctiveness to refuse trade mark protection in respect of goods and services concerning the work and life of the actress, such as books, magazines, photographs, posters, CDs, DVDs, musical performances and film productions. In respect of these goods and services, the public would perceive the portrait photograph as a mere indication of product characteristics. ${ }^{132}$ Hence, the Court argued that the genuine cultural meaning underlying the photograph - showing the head of Marlene Dietrich - rendered the sign descriptive and incapable of serving as a trade mark in respect of goods and services closely related to the work and life of the actress.

\footnotetext{
126 EFTA Court, ibid., para. 65.

127 EFTA Court, ibid., paras. 75-76.

128 EFTA Court, ibid., paras. 75-77.

129 EFTA Court, ibid., para. 78. As to the appropriateness of this conclusion, see Anemaet (2016), pp. 331-332; Senftleben (2013a), pp. 812-813; Ramsey (2003), p. 1150; Denicola (1982), p. 170.

130 German Federal Patent Court, 9 November 2005, case 29 W (pat) 147/03, "Porträtfoto Marlene Dietrich", in: Gewerblicher Rechtsschutz und Urheberrecht 2006, 333, para. 4.2.

131 German Federal Supreme Court, 24 April 2008, case I ZB 21/06, Marlene-Dietrich-Bildnis, para. 11.

132 German Federal Supreme Court, 24 April 2008, case I ZB 21/06, Marlene-Dietrich-Bildnis, paras. 12-15. For relevant case precedents, see German Federal Supreme Court, 5 December 2002, case I ZB 19/00, Winnetou, p. 6; German Federal Supreme Court, 23 January 2003, case I ZR 171/00, Winnetous Rückkehr, p. 10.
} 
This solution of the case has its price. In contrast to the shape exclusion which had been invoked by the German Federal Patent Court, the hurdle of a lack of distinctiveness because of descriptive character can be surmounted once the sign becomes distinctive as a result of the use made of it in trade. ${ }^{133}$ Accordingly, the Federal Supreme Court had to leave the door open to the possibility of the Marlene Dietrich photograph becoming distinctive with regard to goods and services related to the life and work of the actress at a later stage. ${ }^{134}$ The Court added that the portrait photograph was inherently distinctive with regard to merchandising articles, such as scarves, hats, shirts and shoes. In this respect, it rejected the view expressed by the Federal Patent Court that consumers would perceive the portrait as a mere marketing tool and fail to understand that it served as an indication of commercial source. ${ }^{135}$ The Federal Supreme Court emphasized instead that the photograph did not necessarily need to be placed prominently on the articles. It could also be used as a label attached to the goods. Given this option of use as a badge of origin, distinctive character could not be denied. ${ }^{136}$

The photograph of Marlene Dietrich could thus be registered as a trade mark in respect of merchandising articles which are only loosely connected with the actress. A refusal practice focusing on non-distinctiveness, descriptiveness or genericness thus opens the door for the acquisition of trade mark rights to names and symbols with cultural significance. As long as the goods or services involved keep a sufficient distance from the cultural meaning of affected signs and cultural activities, trade mark offices and courts are incapable of preventing the impoverishment of the public domain - understood as the legal status of being unencumbered with intellectual property rights. ${ }^{137}$

The central risk factor, then, is the further development of the sign. Will use as a trade mark for merchandising articles really be confined to use on labels attached to scarves, hats, shirts and shoes, as assumed by the Federal Supreme Court in the Marlene Dietrich case? Will the trade mark owner refrain from sending cease-anddesist letters to competitors also selling merchandising articles with a portrait of the actress as long as these competitors attach different labels to the goods to indicate a different commercial origin? Will competitors be adventurous enough to run the risk of infringement procedures once they receive such a letter? Or will they stop selling their goods or take a licence to avoid the risk and costs of a potential lawsuit? Will the trade mark owner also send cease-and-desist letters to authors and producers in the core fields of music, books, films and photos even though trade mark rights have been denied in this regard? Will affected authors and (potentially small) production

\footnotetext{
133 Article 3(3) former Trade Mark Directive 2008/95 (Art. 4(4) new Trade Mark Directive 2015/2436) which governs the application of national trade mark law in the EU (and EEA) Member States explicitly offers the possibility of acquiring distinctive character through use with regard to non-distinctive, descriptive and generic signs.

134 German Federal Supreme Court, 24 April 2008, case I ZB 21/06, Marlene-Dietrich-Bildnis, para. 17.

135 German Federal Patent Court, ibid., paras. 8.1 and 8.2.

136 German Federal Supreme Court, ibid., paras. 19-22. See also the confirmation of this points in German Federal Supreme Court, 31 March 2010, case I ZB 62/09, Marlene-Dietrich-Bildnis II, paras. 20-28.

137 EFTA Court, ibid., para. 66.
} 
companies simply ignore the threat of legal action after consulting the trade mark register? Will the trade mark owner assert even broader protection going beyond the list of registered goods and services by alleging that the trade mark has become a mark with a reputation enjoying protection with regard to all kinds of goods and services ${ }^{138}$ How will affected authors and producers react to such a further substantiation of the trade mark claim?

These questions shed light on the unreliability of the distinctiveness threshold. The initial denial of trade mark rights in respect of music, books, films and photos in Marlene Dietrich need not discourage further investment in the sign with regard to culturally important market sectors. By contrast, the trade mark owner who already acquired rights in respect of merchandising articles may see the option of strengthening the sign's distinctive character with regard to cultural productions through use in trade as an invitation to make further investments presenting the portrait photograph as a source identifier also in this core area of cultural activity. In case of successful marketing and advertising efforts, trade mark rights may thus finally be granted with regard to music, books, films and photos on the basis of distinctive character acquired as a result of use. In this alternative scenario, the trade mark owner would thus obtain trade mark rights which can have a direct impact on the core area of cultural creativity related to the life and work of Marlene Dietrich. Opting for an approach based on the requirement of distinctive character, the German Federal Supreme Court thus solves the dilemma only provisionally. A refusal based on a lack of distinctiveness does not offer a solution that is sustainable in the sense that it also minimizes the risk of a corrosive effect on cultural follow-on innovation for the future.

Irrespective of these deficiencies, it has become a widespread practice in the EU to refuse trade mark rights in cultural material merely on the basis of a lack of distinctiveness with regard to goods and services that are directly linked with the cultural expression in question. A further example of this approach can be found in the Benelux. In the Anne Frank cases between the Swiss Anne Frank Foundation and the Benelux Office for Intellectual Property, the Brussels Court of Appeal had to decide on the registration of the signs "Het dagboek van Anne Frank" ("The Diary of Anne Frank") and "Het achterhuis" ("The Secret Annex") in respect of books, films and guided tours. Similar to the Vigeland case, the reason for the trade mark application was the fact that the 70-year copyright term relating to the literary works of Anne Frank - held by the Swiss Anne Frank Foundation - was about to expire. ${ }^{139}$ Anne Frank died in the concentration camp Bergen-Belsen in March 1945.

Deciding on the attempt to register "The Diary of Anne Frank" and "The Secret Annex" as trade marks, the Brussels Court of Appeal followed a line of argument similar to the approach taken in the German Marlene Dietrich decision. As the goods and services in question - books, films and guided tours - were directly

\footnotetext{
138 Under the former Trade Mark Directive 2008/95, protection across all kinds of goods and services followed from CJEU, 9 January 2003, case C-292/00, Davidoff/Gofkid. This broad scope has been made explicit in Art. 10(2)(c) new Trade Mark Directive 2015/2436.

139 For further information on the background to this lawsuit, see Van Woensel 2013, pp. 372-373.
} 
connected with Anne Frank's writings and her account of the life of a Jewish family hiding in concealed office rooms from the Nazi terror in Amsterdam, the Benelux Office for Intellectual Property had refused the registration on the grounds that the signs were descriptive and devoid of distinctive character. ${ }^{140}$ Confirming this office decision, the Brussels Court of Appeal pointed out that the titles of literary works constituted an integral part of the works themselves and created a link with their contents. ${ }^{141}$ Against this background, the public would not perceive the signs as identifiers of commercial source but as mere references to Anne Frank's books. For this reason, the signs "The Diary of Anne Frank" and "The Secret Annex" were incapable of serving as distinctive signs with regard to books, films and guided tours. $^{142}$

Agreeing also with the Benelux Office that the signs were descriptive, the Court referred to the Philips/Remington decision of the CJEU and recalled the public interest in keeping certain signs free for competitors and the public at large. ${ }^{143}$ The Court warned of the risk of artificially perpetuating copyright exclusivity after the expiry of copyright protection, and granting the Anne Frank Foundation an indefinitely renewable exclusive right with regard to a work belonging to the universal cultural heritage - a monopoly position which not even Anne Frank's heirs enjoy. ${ }^{144}$ Finally, the Court rejected the argument advanced by the Swiss Anne Frank Foundation that the signs had acquired distinctive character vis-à-vis books, films and guided tours as a result of the use made of them in trade. ${ }^{145}$

The decision clearly reflects the Court's intention to prevent an artificial perpetuation of copyright exclusivity and keep the culturally important indications "The Diary of Anne Frank" and "The Secret Annex" free. Nonetheless, even this court decision cannot fully conceal the weakness of the requirement of distinctive character in comparison with an outright exclusion of trade mark protection. While emphasizing the inaptness of the signs to distinguish books, films and guided tours related to Anne Frank's hiding place and writings, the Court also acknowledged that a trade mark registration of book titles was possible in respect of goods and services that are independent of the works they identify. ${ }^{146}$ As with the German Federal Supreme Court in the Marlene Dietrich decision, ${ }^{147}$ the Brussels Court of Appeal thus conceded that a trade mark registration in respect of merchandising articles was conceivable. $^{148}$

\footnotetext{
140 Brussels Court of Appeal, 3 October 2013, cases 2013/7132 and 2013/7133, Anne Frank Foundation/ Benelux Office for Intellectual Property, para. 1.

141 Brussels Court of Appeal, ibid., para. 5.

142 Brussels Court of Appeal, ibid., paras. 6 and 10.

143 Brussels Court of Appeal, ibid., para. 7, and CJEU, 18 June 2002, case C-299/99, Philips/Remington, para. 78.

144 Brussels Court of Appeal, ibid., paras. 7 and 10.

145 Brussels Court of Appeal, ibid., para. 8.

146 Brussels Court of Appeal, ibid., para. 5.

147 German Federal Supreme Court, 24 April 2008, case I ZB 21/06, Marlene-Dietrich-Bildnis, paras. $19-22$.

148 Brussels Court of Appeal, ibid., para. 5.
} 
Moreover, the decision contains a separate section discussing whether "The Diary of Anne Frank" and "The Secret Annex" had acquired distinctive character vis-à-vis books, films and guided tours through use in the course of trade. ${ }^{149}$ While the Court finally denied this question, the attention devoted to this point clearly shows that it cannot be ruled out that culturally important signs become distinctive even in respect of goods and services that are directly connected with their cultural meaning. At EU level, the registration of "Le Journal de l'Anne Frank" has even been accepted in respect of films, books and theatre plays in the meantime. ${ }^{150}$ Considering this weakness of a refusal based on a lack of distinctiveness, it is of particular importance that the EFTA Court clearly points out the volatility of a refusal based on non-distinctiveness, descriptiveness or genericness.

In comparison with these distinctiveness-based grounds for refusal, the doctrine of aesthetic functionality in EU trade mark law - the exclusion of signs that give substantial value to the goods ${ }^{151}$ - offers a more robust ground for refusing trade mark rights. In respect of products that incorporate Vigeland's sculptures and designs, such as decorative items and furniture, considerations of aesthetic functionality can lead to a ban on trade mark protection that cannot be overcome through use in trade. ${ }^{152}$ Nonetheless, the EFTA Court is critical about this refusal option because services are not covered from the outset and a registration in respect of goods that are unrelated to the sign's initial context may have success. ${ }^{153}$ Therefore, the Court concludes that the exclusion of trade mark protection on the basis of substantial value considerations "does not ensure that works, in general, are kept within the public domain." 154

In the light of the Marlene Dietrich decision of the German Federal Supreme Court, a trade mark application also seems immune from a refusal based on substantial value considerations when it is argued that the cultural signs concerned would only be attached to the goods as a label. As explained, the Federal Supreme Court emphasized in Marlene Dietrich that the portrait photograph at issue did not have to be placed prominently on the articles. It could also be used as a label attached to the goods. ${ }^{155}$ If merely used as a label, a cultural sign can hardly be found to add substantial value to the goods. Otherwise, the brand value which the sign represents in the form of the label, would be sufficient to assume aesthetic functionality and invoke the exclusion based on substantial value considerations.

\footnotetext{
149 Brussels Court of Appeal, ibid., para. 8.

150 OHIM Board of Appeal, 31 August 2015, case R 2401/2014-4, Anne Frank Fonds ("Le Journal d'Anne Frank"), paras. 32-36.

151 Article 3(1)(e)(iii) former Trade Mark Directive 2008/95 and Art. 4(1)(e)(iii) new Trade Mark Directive 2015/2436.

152 EFTA Court, ibid., paras. 79 and 81

153 EFTA Court, ibid., para. 81.

154 EFTA Court, ibid., para. 81.

155 German Federal Supreme Court, 24 April 2008, case I ZB 21/06, Marlene-Dietrich-Bildnis, paras. 19-22. See also the confirmation of this points in German Federal Supreme Court, 31 March 2010, case I ZB 62/09, Marlene-Dietrich-Bildnis II, paras. 20-28. However, see also CJEU, 26 April 2012, case C-307/11 P, Deichmann/OHIM, paras. 54-56; and CJEU, 10 November 2016, case C-30/15 P, Simba Toys/EUIPO (Rubik's Cube), paras. 46-52, for a more concrete assessment of the method of use.
} 
This, in turn, would lead to a circular line of reasoning and the exclusion of any sign with brand value from trade mark protection. For example, the attachment of the Coca Cola logo to soft drinks would also lead to an exclusion of trade mark rights because the brand value of the logo adds substantial value to the product. To avoid this absurd result, use as a label necessarily falls outside the scope of the exclusion of signs giving substantial value to the goods. The EFTA Court thus has a point when holding that considerations of aesthetic functionality are unreliable, weak safeguards as well - even though they seem more effective than a refusal based on a lack of distinctiveness.

\subsection{Public Policy and Principles of Morality}

In the Vigeland decision, the qualification of distinctiveness and aesthetic functionality as insufficient guarantees of the public domain status (in the sense of absence of any intellectual property protection) finally leads to a closer inspection of the option to refuse registration because of a conflict with public order or accepted principles of morality. This ground for refusal has the broadest exclusionary effect: it cannot be overcome through use in trade, and it is not confined to specific goods or services. ${ }^{156}$ The EFTA Court makes a first contribution to the further development of this ground for refusal by clearly distinguishing its two branches: a refusal based on grounds of public policy requires an assessment of objective criteria, whereas a refusal based on accepted principles of morality implies the examination of subjective values. ${ }^{157}$

As to the subjective criterion of a conflict with accepted principles of morality, the Court underlines the necessity to examine on a case-by-case basis how the relevant public would perceive the sign at issue. In line with previous EU case law, ${ }^{158}$ the Court poses the question whether Vigeland's works - in and of themselves - would be considered offensive by reasonable consumers with average sensitivity and tolerance thresholds. ${ }^{159}$ Quite clearly, this question can be answered in the negative. ${ }^{160}$ The EFTA Court, however, goes beyond this standard analysis and adds an important nuance by holding that

certain pieces of art may enjoy a particular status as prominent parts of a nation's cultural heritage, an emblem of sovereignty or of the nation's

\footnotetext{
156 EFTA Court, ibid., para. 82. However, see also Kur (2017), section 3(a) and (d), who recommends a solution based on an assessment of bad faith instead of the invocation of public order or principles of morality. As the bad faith assessment confines the solution to specific cases where bad faith can be found, this alternative does not solve the problem of dysfunctional incentives for investment in the development of cultural heritage trade marks and the described corrosive effect on cultural follow-on innovation. The solution developed by the EFTA Court is thus preferable.

157 EFTA Court, ibid., paras. 84-86. As to the innovative character of the decision, see Kur (2017), section 3(a), and Geiger and Machado Pontes, pp. 11-12, who place the judgment in the context of previous EU office and court practice.

158 For an overview, see Geiger and Machado Pontes (2017), pp. 8-11; Kur and Senftleben (2017), paras. 4.205-4.218; ECS (2017), pp. 459-460.

159 EFTA Court, ibid., paras. 89-90 and 93.

160 EFTA Court, ibid., para. 91.
} 
foundations and values. A trade mark registration may even be considered a misappropriation or a desecration of the artist's work, in particular if it is granted for goods or services that contradict the values of the artist or the message communicated through the artwork in question. Therefore, the possibility cannot be ruled out that trade mark registration of an artwork may be perceived by the average consumer in the EEA State in question as offensive and therefore as contrary to accepted principles of morality. ${ }^{161}$

This addition is remarkable. With this statement, the EFTA Court departs from the traditional focus on the scandalous nature of the sign itself. A refusal based on accepted principles of morality may also follow from a finding that the relevant public perceives the trade mark registration of an artwork as offensive. ${ }^{162}$ In this way, the EFTA Court substantially broadens the field of application of the ground for refusal. While in the past the offensive nature of the sign was decisive, the offensive nature of the registration attempt offers an alternative avenue for a refusal in the view of the EFTA Court. In consequence, the assessment must take into account the status or perception of the artwork in the relevant national context and the nature of the goods or services for which registration as a trade mark has been applied, "such that registration must be refused if the work is being misappropriated." 163

As to the second branch of the ground for refusal - the objective criterion of a conflict with public policy - the EFTA Court notes that "public policy" refers to principles and standards regarded to be of a fundamental concern to the State and the whole of society. Therefore, a refusal based on public policy requires exceptional circumstances, namely "a genuine and sufficiently serious threat to a fundamental interest of society." ${ }^{164}$ Nonetheless, the Court sees room for applying this ground for refusal in the context of artwork registrations: "An artwork may be refused registration, for example, under the circumstances that its registration is regarded as a genuine and serious threat to certain fundamental values or where the need to safeguard the public domain, itself, is considered a fundamental interest of society." 165

The EFTA Court can hardly be expected to embark on a more concrete assessment of the situation surrounding the application filed by the Municipality of Oslo. Given the discretion enjoyed by the national authorities in this respect, it is for the Norwegian office and courts to determine whether these requirements are met in the Vigeland case. Interestingly, the Czech Republic had submitted a statement to the EFTA Court referring to "a fundamental interest of society in leaving certain famous pieces of art available to everyone, such as well-known and outstanding

\footnotetext{
161 EFTA Court, ibid., para. 92.

162 EFTA Court, ibid., para. 92. For a national precursor of this broad interpretation in the context of religious signs, see Kur (2017), section 3(a). For the discussion of a similar concept of "cultural offensiveness" that has evolved in New Zealand in respect of signs of indigenous peoples, see Frankel (2005), pp. 87-91.

163 EFTA Court, ibid., para. 93.

164 EFTA Court, ibid., paras. 94-96.

165 EFTA Court, ibid., para. 96.
} 
creations of mind that are part of the universal cultural heritage."166 This statement shows that national authorities may be willing to adopt the approach developed by the EFTA Court in the Vigeland decision.

As in the context of accepted principles of morality, the EFTA Court states that a genuine and serious threat to public policy can follow from the trade mark registration of an artwork. ${ }^{167}$ Hence, the Court confirms that not only the nature of the sign at issue but also the registration attempt as such can be sufficient to justify a refusal based on Art. 3(1)(f) of the former Trade Mark Directive 2008/95 (Art. 4(1)(f) of the new Trade Mark Directive 2015/2436). The scope of the ground for refusal is thus broadened substantially.

Furthermore, the EFTA Court provides exemplary lines of argument that could support an exclusion of artworks from trade mark protection on the basis of public policy or accepted principles of morality at the national level. In this way, the Court paves the way for including principles of morality and public policy in the canon of grounds for refusal that are relevant to the assessment of registration attempts relating to signs with cultural significance. In the light of the described concerns about an impediment of cultural follow-on innovation, this is a welcome and overdue step in the right direction.

Ultimately, the EFTA Court also outlines the limits of its approach. The application of public policy or principles of morality as grounds for refusal must not lead to a rejection automatism. The Court makes it clear that "the fact that an artwork has previously enjoyed copyright protection may not in itself form the basis for refusing trade mark registration." 168 Moreover, no threat to the need to safeguard the public domain can be found in the case of works that were primarily created to serve as signs to be registered as trade marks (where cumulative copyright and trade mark protection is merely incidental), or in the case of signs which, albeit based on a work pertaining to the public domain, contain additional elements that transform or diffuse the original work to such an extent that consumers are unlikely to confuse the sign with the original creative work. ${ }^{169}$

\section{Other Findings}

In comparison with the fresh guidelines for the application of public policy and principles of morality as grounds for refusal, the Vigeland decision does not yield new insights with regard to the other points raised in the prejudicial questions. It does not come as a surprise that the Court takes the view that the exclusion of substantial value shapes in Art. 3(1)(e)(iii) of the former Trade Mark Directive $2008 / 95$ is applicable to two-dimensional representations of three-dimensional shapes, such as Vigeland's sculptures. ${ }^{170}$ In the earlier case Pi-Design and Bodum/

\footnotetext{
166 Report for the Hearing, Judge-Rapporteur Baudenbacher, 5 October 2016, case E-5/16, Municipality of Oslo ("Vigeland"), para. 118

167 EFTA Court, ibid., para. 96.

168 EFTA Court, ibid., para. 88.

169 EFTA Court, ibid., paras. 97-98.

170 EFTA Court, ibid., paras. 112 and 115.
} 
Yoshida, the GCEU had already taken the view that the wording of the shape exclusions in EU trade mark law did not define the signs which had to be considered as relevant shapes. The provision made no distinction between three-dimensional shapes, two-dimensional shapes, or two-dimensional representations of threedimensional shapes. For this reason, the GCEU had held that the exclusion of technical shapes covered "any sign, whether two- or three-dimensional, where all the essential characteristics of the sign perform a technical function."171 The Vigeland decision is in line with this case precedent. Under Art. 4(1)(e)(iii) of the new Trade Mark Directive 2015/2436, the question has become obsolete anyway. The amended version of the EU functionality doctrine comprises not only the shape of goods but also other characteristics, including two-dimensional features.

With regard to the clarification sought in respect of non-distinctiveness and descriptiveness as grounds for refusal, the European Commission had submitted that a relevant assessment factor could be whether the characteristics of a sign were, in the public's perception, purely attributable to the ornamental and decorative nature of the goods, rather than indicating the commercial origin of the goods. ${ }^{172}$ The EFTA Court, however, only clarified the interplay of the two grounds for refusal: descriptiveness implies non-distinctiveness; non-descriptiveness does not preclude an examination of non-distinctiveness. ${ }^{173}$

\section{Conclusion}

With regard to the preservation of the public domain of cultural creations, the Vigeland decision of the EFTA Court is a milestone. It paves the way for an important and welcome recalibration of the copyright/trade mark interface. The Court departs from the traditional approach which relies on non-distinctiveness, descriptiveness or genericness to reject trade mark rights. Instead, the Court provides exemplary lines of argument for the application of considerations of public policy or principles of morality as grounds for refusal. As a refusal based on these grounds cannot be set aside once distinctiveness is acquired through use in trade, the rejection of a registration request leads to an outright exclusion from trade mark protection and a robust preservation of a work's public domain status.

Moreover, considerations of public policy and principles of morality, as interpreted by the Court, offer trade mark offices and courts room to clearly articulate cultural concerns - in particular the need to prevent an impediment of cultural follow-on innovation - in the context of a rejection of trade mark protection. With the Vigeland decision, it becomes possible to state candidly that trade mark law is not intended to serve as a basis for free-riding on the reputation and positive image of cultural symbols, the blurring of a sign's genuine cultural meaning through the attachment of commercial connotations, the reduction of a sign's cultural value as a result of exposure to commercial marketing strategies, and

\footnotetext{
171 General Court, 8 May 2012, case T-416/10, Pi-Design and Bodum/Yoshida, paras. 24 and 27.

172 EFTA Court, ibid., para. 132.

173 EFTA Court, ibid., para. 141. Cf. ECS (2017), pp. 463.
} 
the impairment of the unhindered, open communication process surrounding the sign in the cultural domain.

With its decision, the EFTA Court also paves the way for the elimination of a serious imbalance within the intellectual property system. Whereas the doctrine of technical functionality can be employed to draw a boundary line between trade mark and patent protection, and the doctrine of aesthetic functionality offers an effective tool to police the border between trade mark and industrial design protection, comparable instruments to separate trade mark protection from copyright protection have not been developed yet. As in the case of overlaps with patent and industrial design rights, however, indefinitely renewable trade mark rights involve the risk of an artificial extension of the limited term of copyright protection (in the case of simultaneous trade mark protection) and the impoverishment of the public domain of cultural expressions (in the case of subsequent trade mark protection).

The Vigeland decision has the potential to fill this gap. According to the EFTA Court, public policy and principles of morality can serve as grounds for refusal not only when a sign is perceived as problematic in and of itself, but also when the registration of an artwork as a trade mark is deemed problematic. As a result of this considerable broadening of the field of application, considerations of public policy and principles of morality could play a role in policing the border between copyright and trade mark protection that is comparable with the role fulfilled by the functionality doctrine in respect of the patent/trade mark interface and the industrial design/trade mark interface.

After all, it is difficult to understand why, to this day, there is broad consensus in trade mark law that technical solutions, such as the Philishave razor system and the Lego brick, ${ }^{174}$ must be kept free, whereas no clear-cut answer can be given when an attempt is made to register a cultural creation, such as the Mona Lisa or Gustav Vigeland's Angry Boy. Is freedom to use technical solutions really so much more important than freedom to use works of art? Even in the case of works belonging to the universal cultural heritage?

To remedy this imbalance, national offices and courts should follow in the footsteps of the EFTA Court. Invoking public policy and principles of morality, they can avoid that trade mark law provides dysfunctional incentives for the reprivatization of cultural public domain material. They can also avoid that public money, such as the financial resources of the city of Oslo, is spent to acquire and maintain a trade mark portfolio of artworks. Arguably, this money should be invested in primary public tasks instead. Why not invest more in the work of art academies and cultural heritage institutions, such as museums and archives?

Open Access This article is distributed under the terms of the Creative Commons Attribution 4.0 International License (http://creativecommons.org/licenses/by/4.0/), which permits unrestricted use, distribution, and reproduction in any medium, provided you give appropriate credit to the original author(s) and the source, provide a link to the Creative Commons license, and indicate if changes were made.

\footnotetext{
174 CJEU, 18 June 2002, case C-299/99, Philips/Remington, paras. 78-82; CJEU, 14 September 2010, case C-48/09 P, Lego/Mega Brands, para. 43.
} 


\section{References}

Amabile TM (1996) Creativity in context. Westview Press, Boulder

Anemaet L (2016) The public domain is under pressure: why we should not rely on empirical data when assessing trademark distinctiveness. Int Rev Intellect Prop Compet Law 47:303

Assaf K (2009) Der Markenschutz und seine kulturelle Bedeutung: Ein Vergleich des deutschen mit dem US-amerikanischen Recht. Gewerblicher Rechtsschutz und Urheberrecht-Internationaler Teil 58:1

Aufderheide P, Jaszi P (2004) Untold stories: creative consequences of the rights clearance culture for documentary filmmakers. American University, Washington D.C

Banerjee A (2012) Non-origin infringement-has trade mark law gone too far? Int Rev Intellect Prop Compet Law 43:555

Beebe B (2006) A defense of the new federal trademark antidilution law. Fordham Intellect Prop Media Entertain Law J 16:1143

Benkler Y (1999) Free as the air to common use: first amendment constraints on enclosure of the public domain. N Y Univ Law Rev 74:354

Bourdieu P (1992) Die Regeln der Kunst. Genese und Struktur des literarischen Feldes, Frankfurt/Main: Suhrkamp 1999 (French original: P. Bourdieu, Les règles de l'art. Genèse et structure du champ littéraire, Paris: Éditions du Seuil 1992)

Bouvel A (2010) Marques et renommée: À propos de l'arrêt "Intel" rendu par la Cour de justice des communautés européennes le 27 novembre 2008 (aff. C-252/07). In: Geiger C, Schmidt-Szalewski J (eds) Les défis du droit des marques au XXIe siècle. Litec, Strasbourg, p 123

Bugdahl V (2010) Marken und Kunst - Kunst und Marken. Markenrecht:369

Calboli I (2014a) Overlapping trademark and copyright protection: a call for concern and action. Ill Law Rev Slip Opin 1:25

Calboli I (2014b) Overlapping rights: the negative effects of trademarking creative works. In: Frankel S, Gervais DJ (eds) The evolution and equilibrium of copyright in the digital age. Cambridge University Press, Cambridge, p 52

Cohen JE (2006) Copyright, commodification, and culture: locating the public domain. In: Guibault LMCR, Hugenholtz PB (eds) The future of the public domain-identifying the commons in information law. Kluwer Law International, The Hague/London/New York, p 121

Cohen Jehoram T, van Nispen CJJC, Huydecoper JLRA (2010) European trademark law. Kluwer Law International, Alphen aan den Rijn

Conley N, Braegelmann T (2009) Metall auf Metall: the Importance of the Kraftwerk decision for the sampling of music in Germany. J Copyr Soc USA 56:1017

Davison M, Di Giantomasso F (2009) Use as a trade mark: avoiding confusion when considering dilution. Eur Intellect Prop Rev 31:443

Denicola RC (1982) Trademarks as speech: constitutional implications of the emerging rationales for the protection of trade symbols. Wis Law Rev 158:158

Derclaye E, Leistner M (2011) Intellectual Property Overlaps - A European Perspective. Oxford and Portland, Oregon: Hart Publishing 2011

Dinwoodie GB, Janis MD (2007) Confusion over use: contextualism in trademark Law. Iowa Law Rev 92:1597

Dogan SL, Lemley MA (2008) The trademark use requirement in dilution cases. Santa Clara Comput High Technol Law J 24:541

Dougherty FJ (2007) RIP, MIX and BURN: Bemerkungen zu aktuellen Entwicklungen im Bereich des digitalen Sampling nach US-amerikanischem und internationalen Recht. Gewerblicher Rechtsschutz und Urheberrecht-Internationaler Teil, p 481

European Copyright Society (2017) Trade mark protection of public domain works: a comment on the request for an advisory opinion of the EFTA court: case E-05/16: Norwegian Board of Appeal for Industrial Property Rights-Appeal from the Municipality of Oslo. Eur Intellect Prop Rev 39:457

Frankel SR (2005) Third-party trade marks as a violation of indigenous cultural property-a new statutory safeguard. J World Intellect Prop 8:83

Frankel SR (2008) Trademarks and traditional knowledge and cultural intellectual property rights. In: Dinwoodie GB, Janis MD (eds) Trademark law and theory: a handbook of contemporary research. Edward Elgar Publishing, Cheltenham, p 433 
Geiger C, Machado Pontes L (2017) Trade mark registration, public policy, morality and fundamental rights. Centre for International Intellectual Property Studies Research Paper No. 2017-01. CEIPI, Strasbourg

Gibson J (2007) Risk aversion and rights accretion in intellectual property law. Yale Law J 116:882

Götting H-P (2001) Persönlichkeitsmerkmale von verstorbenen Personen der Zeitgeschichte als Marke. Gewerblicher Rechtsschutz und Urheberrecht:615

Hofrichter JA (2007) Tool of the trademark: brand criticism and free speech problems with the federal Dilution Revision Act of 2006. Cardozo Law Rev 28:1923

Kirchhof P (1988) Der Gesetzgebungsauftrag zum Schutz des geistigen Eigentums gegenüber modernen Vervielfältigungstechniken. R. v. Decker \& C.F. Müller, Heidelberg

Klinkert F, Schwab F (1999) Markenrechtlicher Raubbau an gemeinfreien Werken-ein richtungsweisendes „Machtwort“durch den Mona Lisa-Beschluss des Bundespatentgerichts? Gewerblicher Rechtsschutz und Urheberrecht 101:1067

Kreile R (1993) Die Sozialbindung des geistigen Eigentums. In: Badura P, Scholz R (eds) Festschrift für Peter Lerche zum 65. Geburtstag, München, p 251

Kur A (2001) Funktionswandel von Schutzrechten: Ursachen und Konsequenzen der inhaltlichen Annäherung und Überlagerung von Schutzrechtstypen. In: Schricker G, Dreier T, Kur A (eds) Geistiges Eigentum im Dienst der Innovation. Nomos, Baden-Baden, p 23

Kur A (2008) 'Confusion over Use?-Die Benutzung "als Marke” im Lichte der EuGH-Rechtsprechung. Gewerblicher Rechtsschutz und Urheberrecht-Internationaler Teil, p 1

Kur A (2011) Too pretty to protect? Trade mark law and the enigma of aesthetic functionality. Max Planck Institute for Intellectual Property \& Competition Law Research Paper No. 11-16, Max Planck Institute, Munich

Kur A (2017) Gemeinfreiheit und Markenschutz-Bemerkungen zur Entscheidung des EFTA-Gerichtshofs im Vigeland-Fall. Gewerblicher Rechtsschutz und Urheberrecht (forthcoming)

Kur A, Senftleben MRF (2017) European trade mark law-a commentary. Oxford University Press, Oxford

Leistner M (2016) Die 'Metall auf Metall'-Entscheidung des BVerfG-Oder: Warum das Urheberrecht in Karlsruhe in guten Händen ist. Gewerblicher Rechtsschutz und Urheberrecht:772

Lemley MA, McKenna MP (2010) Owning Mark(et)s. Mich Law Rev 109:137

Lessig L (2004) Free culture: how big media uses technology and the law to lock down culture and control creativity. Penguin Press, New York

Loughlan PL (2000) Protecting culturally significant uses of trade marks (without a first amendment). Eur Intellect Prop Rev 22:328

McCarthy JT (2004) Dilution of a trademark: European and United States law compared. Trademark Rep 94:1163

McGeveran W (2008) Four free speech goals for trademark law. Fordham Intellect Prop Media Entertain Law J 18:1205

McGuire M-R (2011) Kumulation und Doppelschutz - Ursachen und Folgen des Schutzes einer Leistung durch mehrere Schutzrechte. Gewerblicher Rechtsschutz und Urheberrecht:767

McKenna MP (2009) Trademark use and the problem of source. Univ Ill Law Rev 2009:773

Middlemiss S, Warner S (2009) The protection of marks with a reputation: Intel v CPM. Eur Intellect Prop Rev 2009:326

Morrison DM (2008) Bridgeport redux: digital sampling and audience recoding. Fordham Intellect Prop Media Entertain Law J 19:75

Nordemann W (1997) Mona Lisa als Marke. Wettbewerb in Recht und, Praxis, p 389

Ohly A (2008) Von einem Indianerhäuptling, einer Himmelsscheibe, einer Jeans und dem Lächeln der Mona Lisa-Überlegungen zum Verhältnis zwischen Urheber- und Kennzeichenrecht. In: Pahlow L, Eisfeld J (eds) Grundlagen und Grundfragen des Geistigen Eigentums, Festgabe für Diethelm Klippel zum 65. Geburtstag, Mohr Siebeck, Tübingen, p 203

Ohly A (2009) Keyword-Advertising auf dem Weg von Karlsruhe nach Luxemburg. Gewerblicher Rechtsschutz und Urheberrecht 111:709

Osenberg R (1996) Markenschutz für urheberrechtlich gemeinfreie Werkteile. Gewerblicher Rechtsschutz und Urheberrecht 98:101

Peukert A (2012) Die Gemeinfreiheit. Mohr Siebeck, Tübingen

Podszun R (2016) Postmoderne Kreativität im Konflikt mit dem Urheberrechtsgesetz und die Annäherung an 'fair use. Zeitschrift für Urheber- und Medienrecht 60:606 
Quaedvlieg AA (2009) INTEL en verwatering: Economisch gedrag en juridisch bewijs. Bijblad bij de industriële eigendom:253

Quaedvlieg AA (2009) Herkomst- en goodwillinbreuk in het merkenrecht na INTEL en l'Oréal. Ars Aequi:799

Quanjel-Schreurs RAM (2007) Enkele procesrechtelijke aspecten van cumulatie van auteurs- en merkenrecht, naar aanleiding van het Benetton/G-Star-arrest. Tijdschrift voor auteurs-, media- en informatierecht:76

Ramsey LP (2003) Descriptive trademarks and the first amendment. Tennessee Law Rev 70:1095

Raue B (2010) Nachahmungsfreiheit nach Ablauf des Immaterialgüterrechtsschutzes?. V\&R unipress, Göttingen

Sakulin W (2010) Trademark protection and freedom of expression—an inquiry into the conflict between trademark rights and freedom of expression under European Law. Kluwer Law International, The Hague/London/New York

Samuelson P (2006a) Enriching discourse on public domains. Duke Law J 55:101

Samuelson P (2006b) Challenges in mapping the public domain. In: Guibault LMCR, Hugenholtz PB (eds) The future of the public domain-identifying the commons in information law. Kluwer Law International, The Hague/London/New York, p 7

Schippers BHM (2014) Het chilling effect van Kraftwerk I/II op sound sampling: pleidooi voor zelfregulering ter bevordering van samplegebruik. Tijdschrift voor auteurs-, media- en informatierecht: 105

Schovsbo JH (2018) Mark my words-trademarks and fundamental rights in the EU. UC Irvine Law Review 8 (forthcoming), draft available at https://ssrn.com/abstract=2928031

Seifert F (2000) Markenschutz und urheberrechtliche Gemeinfreiheit. Wettbewerb in Recht und Praxis: 1014

Senftleben MRF (2009) The trademark tower of Babel-dilution concepts in international, US and EC trademark law. Int Rev Intellect Prop Compet Law 40:45

Senftleben MRF (2010) Der kulturelle Imperativ des Urheberrechts. In: Weller M, Kemle NB, Dreier T (eds) Kunst im Markt-Kunst im Recht. Nomos, Baden-Baden, p 75

Senftleben MRF (2011a) Trade mark protection—a black hole in the intellectual property galaxy? Int Rev Intellect Prop Compet Law 42:383

Senftleben MRF (2011b) Keyword advertising in Europe-how the internet challenges recent expansions of EU trademark protection. Conn J Int Law 27:39

Senftleben MRF (2013a) Public domain preservation in EU trademark law-a model for other regions? Trademark Rep 103(4):775

Senftleben MRF (2013b) Adapting EU trademark law to new technologies—back to basics? In: Geiger C (ed) Constructing european intellectual property. Edward Elgar, Cheltenham, p 137

Senftleben MRF (2013c) Trademark Law and the Public Domain. In: Beldiman D (ed) Access to information and knowledge: 21st century challenges in intellectual property and knowledge governance. Edward Elgar, Cheltenham, p 112

Senftleben MRF (2017) Copyright, creators and society's need for autonomous art-the blessing and curse of monetary incentives. In: Giblin R, Weatherall K (eds) What if we could reimagine copyright?. ANU Press, Canberra, p 25

Simon Fhima I (2005) How does "essential function" doctrine drive european trade mark law? Int Rev Intellect Prop Compet Law 36:401

Stieper M (2012) Geistiges Eigentum an Kulturgütern-Möglichkeiten und Grenzen der Remonopolisierung gemeinfreier Werke. Gewerblicher Rechtsschutz und Urheberrecht 114:1083

van Woensel C (2007) Merk, god en verbod. deLex, Amstelveen

Verkade DWF (1998) The cumulative effect of copyright law and trademark law: which takes precedence? In: Kabel JJC, Mom GJHM (eds) Intellectual property and information law-essays in honour of Herman Cohen Jehoram. Kluwer, Den Haag/London/Boston, p 69

Visser DJG (2011) Darfurnica: modellenrecht versus kunstvrijheid. Nederlands Juristenblad:740

Wandtke A, Bullinger W (1997) Die Marke als urheberrechtlich schutzfähiges Werk. Gewerblicher Rechtsschutz und Urheberrecht:573

Yap PJ (2009) Essential function of a trade mark: from BMW to O2. Eur Intellect Prop Rev:81 